\title{
High-resolution palynology reveals the land use history of a Sami renvall in northern Sweden
}

\author{
Ilse M. Kamerling ${ }^{1} \cdot$ J. Edward Schofield $^{1} \cdot$ Kevin J. Edwards $^{1,2} \cdot$ Kjell-Åke Aronsson $^{3}$
}

Received: 15 June 2016/ Accepted: 4 November 2016/Published online: 18 November 2016

(c) The Author(s) 2016. This article is published with open access at Springerlink.com

\begin{abstract}
The limited availability of historical and archaeological evidence means that much is still unknown about the development of Sami reindeer herding in Fennoscandia in both the recent and more distant past. To address this problem, high-resolution palynological analyses, ${ }^{14} \mathrm{C}$ and ${ }^{210} \mathrm{~Pb}$ dating were undertaken on two adjacent $(<25 \mathrm{~m}$ apart) peat profiles collected at a recently abandoned reindeer gathering pen (renvall) near Jokkmokk $\left(\sim 66.6^{\circ} \mathrm{N}, 19.8^{\circ} \mathrm{E}\right)$ in the boreal forest of northern Sweden. The aim was to assess the impact of Sami reindeer herding on the local environment through a study of pollen, coprophilous fungal spores, microscopic charcoal and sedimentology. The samples collected from within an annex to the renvall indicate cycles of use and abandonment of the pen on a multi-decadal timescale between $\sim \mathrm{AD}$ 1800-2008, most obviously in the coprophilous fungal spore archive. The pattern and timing of these cycles confirm events previously known only from oral histories. Although the local pollen assemblage zones associated
\end{abstract}

Communicated by M.-J. Gaillard.

Electronic supplementary material The online version of this article (doi:10.1007/s00334-016-0596-5) contains supplementary material, which is available to authorized users.

Ilse M. Kamerling

ilse.kamerling@abdn.ac.uk

1 Department of Geography and Environment, School of Geosciences, University of Aberdeen, Elphinstone Road, Aberdeen AB24 3UF, UK

2 Department of Archaeology, School of Geosciences, University of Aberdeen, Elphinstone Road, Aberdeen AB24 3UF, UK

3 Ájtte, Swedish Mountain and Sami Museum, Box 116, 96223 Jokkmokk, Sweden with the phasing of activity were reproducible in a second peat core beyond the boundary of the renvall, the coprophilous fungal spore signal in this paired profile was much less distinctive, possibly due to the typically shorter dispersal distances for these microfossils in comparison to pollen grains.

Keywords Forest Sami - Boreal forest · Reindeer herding · Pollen analysis - Coprophilous fungal spores

\section{Introduction}

This paper compares the oral histories of 20th century forest Sami reindeer herding at a recently abandoned gathering pen (renvall) at Akkajärvi, northern Sweden (Fig. 1), with the results of palynological analyses. The aims of this study are:

(i) to assess the response and sensitivity of pollen and various non-pollen palynomorphs (NPPs) to cyclically-recurring reindeer pastoralism at a fixed location in a boreal forest setting;

(ii) to investigate whether patterns revealed in the palaeoecological record match the timing of activity at, and abandonment of the site, as understood from oral histories.

Akkäjarvi featured in an earlier palynological study of forest reindeer herding in Sweden (Aronsson 1991), which showed that such analyses provided a means for detecting and evaluating the landscape response to reindeer pastoralism in northern Fennoscandia. A higher-resolution analysis is presented here, supplemented by an improved site chronology based on the Bayesian modelling of a combined series of ${ }^{210} \mathrm{~Pb}$ and ${ }^{14} \mathrm{C}$ dates (Blaauw and 

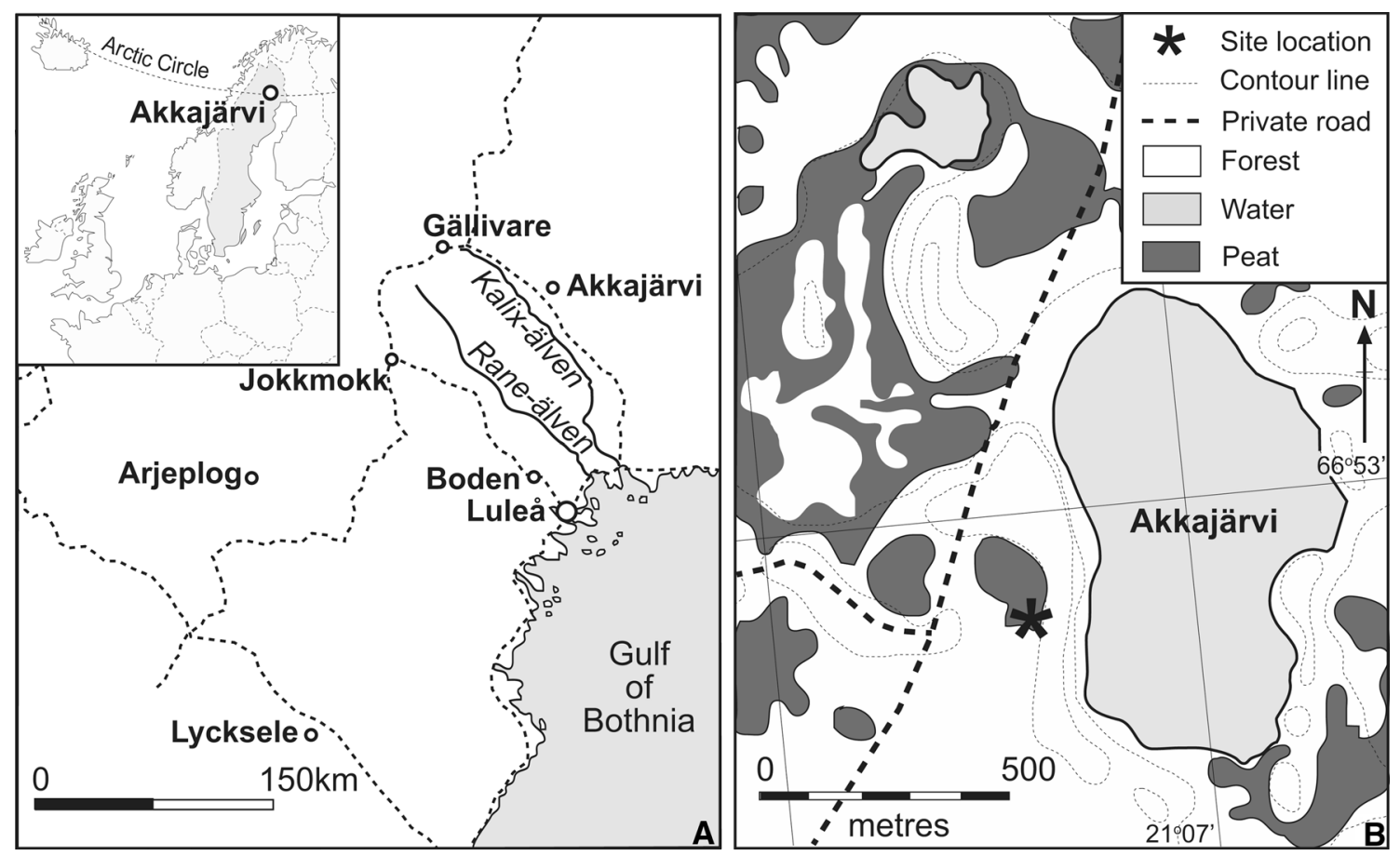

Fig. 1 a Location of the study site at Akkajärvi and other major towns including the winter market town of Jokkmokk; b the location of the renvall close to the lake. Contours are at $5 \mathrm{~m}$ intervals

Christen 2011). The analyses of coprophilous fungal spores, microscopic charcoal and loss-on-ignition (LOI) are incorporated along with pollen analysis (Kuoppamaa et al. 2009). Coprophilous fungal spores offer evidence of biotic impact in the form of livestock grazing and gathering (van Geel et al. 2003; Cugny et al. 2010; Baker et al. 2013). Microscopic charcoal is employed as a measure of fire incidence (Patterson et al. 1987; Ericsson et al. 2000; Niklasson and Granström 2000) which may be linked to the use of domestic and smudge fires, the latter being the lingering smoke-producing fires that protect the reindeer from mosquitoes (van Dyke 1901; Aronsson 1991). LOI is used as a proxy for soil erosion (Edwards and Rowntree 1980; Evans 1996).

The Sami form a cultural group that is currently spread across Sápmi, an area covering northern Norway, Sweden, Finland and the Russian Kola Peninsula. Much remains unknown about their cultural history owing to a scarcity of historical and archaeological evidence. Debate continues over the nature and timing of the domestication of Rangifer tarandus (reindeer) by the Sami, which is variously placed as early as the end of the last glacial (Weichselian) period (Bogoras 1924; Jochelson 1926), the 1st millennium BC (Helskog 1988), the 1st millennium AD (Östlund and Bergman 2006), AD 800-1000 (the Viking Age) (Manker 1947; Ruong 1982), or as late as the 16th-18th century (MüllerWille et al. 2006; Bjørnstad et al. 2012). The transition from hunting to herding (semi-nomadic pastoralism) must have resulted in changes in the relationship between people, their animals and the environment (most notably, the vegetation).

The impacts of Sami reindeer hunting on the environment are believed to have been minimal (Aronsson 1991, 1994), but are distinguishable in the palynological record (Hicks 1993; Bergman et al. 2004a; Hörnberg et al. 2005; Josefsson et al. 2009, 2010), much like hunter-fisher-gatherer societies with partially related lifestyles (Edwards 1996; Edwards et al. 2009; but see Woelders et al. 2016). Historical and palaeoecological data place the transition from reindeer hunting to true, intensive reindeer herding around the 17th or 18th century AD (Aronsson 1991; Lundmark 2007). This method involved the regular gathering of small, tame herds of animals for the purposes of milking, calving, calf marking, slaughtering and protection (Aronsson 1991), while the daily subsistence requirements continued to be met through hunting and gathering (Niklasson et al. 1994; Bergman et al. 2004b; Müller-Wille et al. 2006). Reindeer were lured to their summer herding grounds with the help of peat-fuelled smudge fires. In northern Norrland, extensive reindeer herding replaced the intensive method around 1920-1930. Under this system the herds became larger, control over the animals was reduced, and reindeer milk was replaced by that of cows and also goats as people became more settled. Pens previously used for reindeer milking were increasingly used for summer calf-marking.

Four main effects of recurring activity during the 16th to 19 th centuries at semi-permanent Sami reindeer herding 
settlements in the Arjeplog area $\left(\sim 66.1^{\circ} \mathrm{N} 17.9^{\circ} \mathrm{E}\right.$; Fig. 1) were proposed by Freschet et al. (2014): (1) organic matter deposition, both by the Sami and their herds; (2) soil compaction through trampling; (3) destruction of the field layer; (4) selective felling of Pinus sylvestris for fuel and building purposes. Palynologically, the creation of local openings in the boreal forests of northern Fennoscandia, to provide spaces for dwellings and livestock, is recognizable by a decline in trees (Hicks 1976; Vuorela 1976; Berglund et al. 2008). An increase in Poaceae forms the main response among non-arboreal taxa, but the strength of this signal in the palynological record weakens with increasing distance from the disturbance (Suominen 1975; Aronsson 1991; Hicks 1993; Aronsson 1994).

A set of plants that is indicative of reindeer herding in the boreal forests of northern Sweden has been identified by Aronsson (1991); representative pollen types include Poaceae, Melampyrum, Solidago virgaurea, Achillea millefolium, Epilobium angustifolium, Rumex acetosal acetosella, Chenopodium, Silene dioica and Urtica. These taxa respond positively to increased light levels following clearance, are resistant to soil trampling and typically react positively to the increased soil nutrient levels provided by inputs from reindeer dung, domestic waste and ash from smudge fires. Recovery following the abandonment of disturbed areas is characterised by a general secondary succession whereby the Poaceae-dominated vegetation is replaced first by ericaceous heaths and Betula, then by Pinus and finally by Picea (Bradshaw and Zackrisson 1990; Jonsson and Esseen 1998; Freschet et al. 2014). This recovery may take considerably longer than the duration of human impact, grazing activity and the resulting nitrogen enrichment (Walker and Wardle 2014). At reindeer herding settlements near Arjeplog (450-550 m a.s.l.), secondary succession was still underway more than 100 years after abandonment, with the old activity areas forming islands of $B$. pubescens within the $P$. sylvestris-dominated forest (Freschet et al. 2014). Once the vegetation within the renvall has recovered, it barely stands out from the surrounding forest, and can be recognised only by larger specimens of trees that had been left to provide shade for the reindeer (Östlund et al. 2003).

\section{Study site}

\section{Cultural history}

Akkajärvi is the Finnish translation of the old Sami name Akkajaure (Akka referring to a female divinity, and jaurel järvi meaning lake). This name was given to a lake located $\sim 60 \mathrm{~km}$ northeast of Jokkmokk (Fig. 1b) and is here also used to identify a recently abandoned renvall that was used by the Rattuka group of the Gällivare forest Sami. Aronsson (1991) collected an oral history of the use of the site from Gunnar Nordvall, who gathered reindeer there, and whose grandmother before him used it for reindeer milking. When intensive herding was still in operation, reindeer were gathered here on a daily basis for milking over several consecutive weeks during the summer. One family or group of herders would own up to 20 pens within their pasturing area. The pens were rotated, each being used for several consecutive years. Rotation avoids the spread of reindeer diseases such as foot and mouth disease (Östlund et al. 2003) or calf diphtheria that infest the muddy, trampled soils and which affect calving in the pens to this day. A severe case of a similarly transmitted reindeer disease led to the abandonment of the Akkajärvi renvall around 1910-1920. Nordvall indicated that the pen was reused for calf marking from $\sim 1960-1970$, by which time extensive reindeer herding was being applied. This required an expansion of the renvall, including the addition of an annex and a new hut (phase 2 on Fig. 2). Some large Picea were left standing within the renvall to provide shade for the reindeer. The renvall was abandoned altogether once the wider area became disrupted by tree felling activities during the 1980s. The duration of use of the renvall prior to its abandonment around 1920 is unknown.

\section{Site description}

The renvall is situated at $386 \mathrm{~m}$ a.s.l. on the perimeter of a small fen measuring $\sim 175 \times 120 \mathrm{~m}$, adjacent to Akkajärvi. The site forms part of a plateau between the Kalixälven and Råne-älven rivers, in a region with mountains which are typically $>500 \mathrm{~m}$ a.s.l. Approximately half of the area consists of morainic hills and ridges, while the remainder is covered by lakes and fens. Extensive felling of the boreal forest has taken place in the region, but the study site itself has not been directly affected.

Forest vegetation communities in northern Sweden are generally classified according to their ground layer composition, which at Akkajärvi is of the Vaccinium vitis-idaea or V. myrtillus-type with abundant ground lichens. The surrounding old growth forest is dominated by Picea and Betula spp. Hummocks on the fen are occupied by Sphagnum, Empetrum and Vaccinium with scattered occurrences of P. sylvestris and Betula spp., and Cyperaceae (mainly Eriophorum angustifolium) in the hollows. Poaceae and Vaccinium dominate the dry land ground layer, along with a scattering of Epilobium, Silene dioica, Gnaphalium sylvaticum and Solidago virgaurea. Betula spp. and Pinus saplings are becoming established in the old phase 1 hut area (Fig. 2). This suggests that the abandoned renvall is in the early stages of a post-disturbance secondary succession (Freschet et al. 2014). 


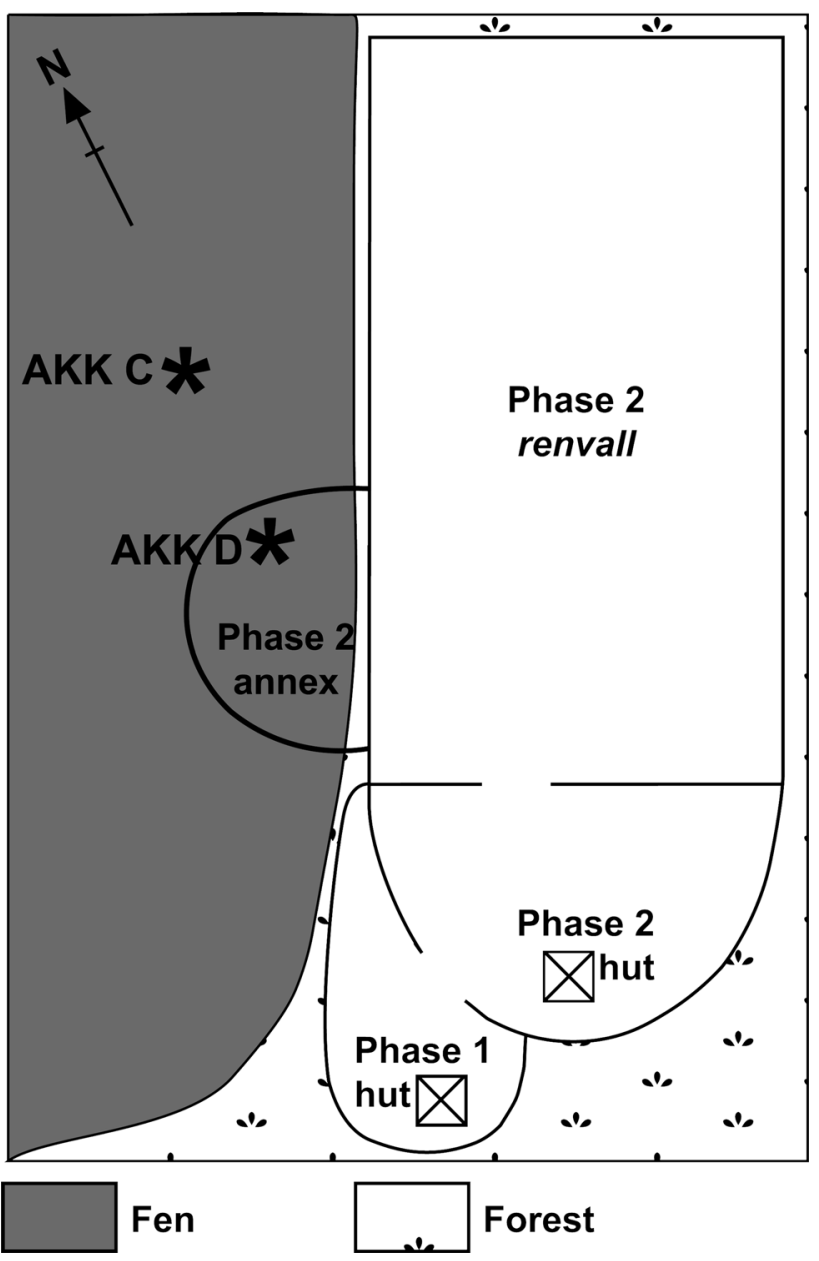

Fig. 2 Schematic plan of the layout of the renvall at Akkajärvi during the intensive (phase 1; pre-c. 1920-1930) and extensive (phase 2; 1970-1990) reindeer herding periods. Sampling locations AKK $\mathrm{D}$ (inside the annex) and AKK C (on the fen) are depicted as stars. The image is not to scale

\section{Methods}

\section{Sample collection}

Two peat profiles were collected to the west of the renvall (Fig. 2), at the base of a gentle slope. The first sequence, AKK D, was collected in a monolith tin from the open face of a soil pit dug within the annex to the renvall $\left(66^{\circ} 52.896^{\prime} \mathrm{N}, 21^{\circ} 06.597^{\prime} \mathrm{E}\right)$, where reindeer were separated from the main herd during the extensive herding phase. It was hoped that the palynomorph record of this peat would contain a clear signal for reindeer herding, although there was some concern that stratigraphic integrity might have been affected through trampling by the animals. Therefore a second (paired) sequence, AKK C $\left(66^{\circ} 52.906^{\prime} \mathrm{N}, 21^{\circ} 06.601^{\prime} \mathrm{E}\right)$, was collected using a Russian corer from the fen approximately $15 \mathrm{~m}$ outside the annex boundary and $25 \mathrm{~m}$ from AKK D (Figs. 2, 3). This profile, though less likely to be disturbed, was anticipated to contain a more muted record of cultural impact.

\section{Sedimentary characteristics}

The stratigraphy of the peat sequences was described using the Troels-Smith (1955) scheme. In order to detect small changes in the minerogenic content of the highly organic peat, LOI was performed by Thermogravimetric Analysis (TGA), which measures weight loss through combustion in a controlled environment to determine the percentage of inorganic matter by weight (Ball 1964; Beaudoin 2003). Analyses were conducted using a Leco Corporation TGA601 in the Sediment Analysis Laboratory at the Vrije Universiteit in Amsterdam. Contiguous $1 \mathrm{~cm}$ samples were dried in an oven at $80{ }^{\circ} \mathrm{C}$ overnight, ground to a powder, heated to $105{ }^{\circ} \mathrm{C}$ to expel $\mathrm{H}_{2} \mathrm{O}$, weighed, and combusted at $550{ }^{\circ} \mathrm{C}$ until weight loss had ceased, usually $\sim 3 \mathrm{~h}$.

\section{Palynology}

Contiguous $1 \mathrm{~cm}$ thick samples of $\sim 1 \mathrm{~cm}^{3}$ were measured by volumetric displacement (Mooney and Tinner 2011). Lycopodium tablets were added to allow the determination of palynomorph concentrations (Stockmarr 1971). Pollen sample preparation followed conventional methods (Moore et al. 1991; Chambers et al. 2011). Samples were mounted unstained in silicone oil (12,500 cSt viscosity) and counted to a sum of $\geq 500$ total land pollen (TLP) using a Nikon E400 binocular light microscope at $400 \times$ magnification and $600 \times$ for critical identifications. Obligate aquatic taxa, spores and exotic long-distance derived pollen types were excluded from the pollen sum. Pollen and spores were identified using the key in Moore et al. (1991) and the reference collection held in the Department of Geography and Environment, University of Aberdeen. Nomenclature largely follows Bennett (2015a). Betula pollen were measured, with those $<20 \mu \mathrm{m}$ classified as $B$. nana (dwarf birch), and grains above this size threshold regarded as tree birch (Mäkelä and Hyvärinen 1998). The uncertainties of this procedure are appreciated fully (Caseldine 2001), but given the low numbers of pollen grains assigned to $B$. nana, this is not considered to be critical.

Coprophilous fungal spores were identified using the notes and photographs in van Geel et al. (2003) and are prefixed HdV- (Hugo-de-Vries laboratory, University of Amsterdam; Feeser and O'Connell 2010). Coprophilous fungal spores are expressed as a percentage of the TLP sum. Microscopic charcoal was quantified through area measurement (Patterson et al. 1987; Conedera et al. 2009; Mooney and Tinner 2011). Only black, opaque, angular particles with a length $\geq 5 \mu \mathrm{m}$ were considered (Patterson et al. 1987; Clark 1988). Charcoal 


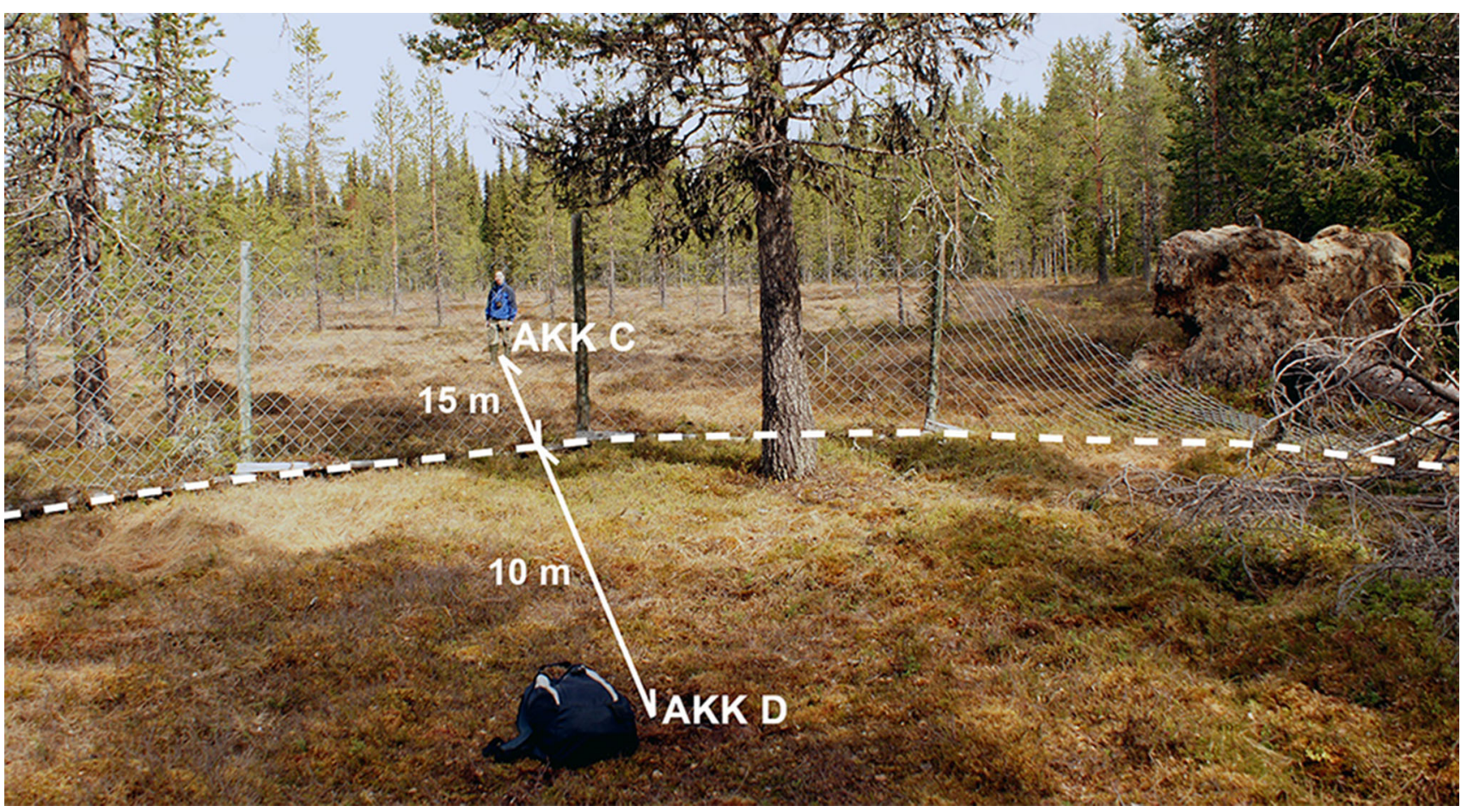

Fig. 3 Photograph showing the relationship between the two sampling locations, Akkajärvi D (AKK D, inside the annexe) and Akkajärvi C (AKK C, out on the fen). The fence line/boundary to the annex of the renvall is indicated by a dashed line. The image is taken inside the annex facing north. (Photograph by I.M. Kamerling 2010) concentrations $\left(\mathrm{cm}^{2} \mathrm{~cm}^{-3}\right)$ were calculated to enable charcoal to pollen ratios $\left(\mathrm{C}: \mathrm{P} ; \mathrm{cm}^{2}\right.$ grain $\left.^{-1}\right)$ to be determined. Calculations of rarefaction - a measure of estimated taxon richness—were made using psimpoll (Bennett 2015b).

Pollen data were collated using Tilia 2.0.b.4 software, and diagrams showing selected taxa were created using TGView 2.0.2 (Grimm 1990). Rare taxa that occurred at trace values $(<1 \%)$ are indicated by a + symbol in the percentage diagrams. The placement of local pollen assemblage zones (LPAZs) was assisted through cluster analysis of the terrestrial pollen taxa using CONISS (Grimm 1987, 1990). Diagrams showing pollen accumulation rates (PAR or influx, measured as palynomorphs $\mathrm{cm}^{-2}$ year $^{-1}$ ) were employed to provide absolute and independent measures of pollen abundance for selected taxa (Davis and Deevey 1964; Seppä and Hicks 2006). Taxa omitted from the selected palynomorph diagrams are shown in ESM Figs. 1, 2.

\section{AMS ${ }^{14} \mathrm{C}$ dating}

Peat samples were disaggregated overnight in $10 \% \mathrm{NaOH}$, sieved through a nest of 250, 180 and $120 \mu \mathrm{m}$ meshes and residues were inspected using a Nikon SMZ645 stereoscopic zoom microscope at $8-50 \times$. Selected plant macrofossils were removed from the sample residues using fine forceps and stored in plastic vials containing distilled $\mathrm{H}_{2} \mathrm{O}$ and a drop of $10 \% \mathrm{HCl}$. Where suitable terrestrial macrofossils were unavailable, the humic acid fraction of bulk $\left(\sim 1 \mathrm{~cm}^{3}\right)$ peat samples was used. Samples were dated at the Scottish Universities Environmental Research Centre (SUERC), East Kilbride. All radiocarbon dates featured in this paper are calibrated using CALIB Version $7.0 \mathrm{html}$ (Stuiver and Reimer 1993; Stuiver et al. 2005) and the IntCal13 calibration curve (Reimer et al. 2013), and are reported at the $2 \sigma$ confidence level.

\section{${ }^{210} \mathrm{~Pb}$ dating}

Contiguous samples of a known volume were dated at $1 \mathrm{~cm}$ resolution. Pre-treatment involved determining the wet bulk density, drying in an oven overnight at $40{ }^{\circ} \mathrm{C}$, and calculating the dry bulk density (Foster et al. 2007). Samples were ground to a powder in a ball grinder and packed into cleaned and pre-weighed $7 \times 1 \mathrm{~cm}$ OD PTFE cylinders, which were filled to $4 \mathrm{~cm}$ height (if $<4 \mathrm{~cm}$, the height of the sediment was recorded). The cylinders were sealed with paraffin wax and stored for at least three weeks before analysis to allow unsupported ${ }^{210} \mathrm{~Pb}$ to equilibrate with ${ }^{222} \mathrm{Rn}$ (Appleby et al. 1986). ${ }^{210} \mathrm{~Pb}$ samples were measured at the University of Northampton and errors were determined according to the constant rate of supply (CRS) model. 


\section{Age-depth models}

In order to construct appropriate chronologies for the profiles under investigation, age-depth models were produced for comparison using both 'classical' age-depth modelling software (Clam; Blaauw 2010) and Bayesian techniques (Bacon; Blaauw and Christen 2011). Within Clam, various model settings were explored (each run with 10,000 iterations) and those with the best 'goodness of fit' were selected. Radiocarbon dates that appeared anomalous, for example those causing age reversals, were omitted. In Bacon, models were run ( $>6.5$ million iterations) using different combinations of prior settings for deposition rate and accumulation shape. Priors were adjusted so that the model intersected the bulk of the probability distributions of the calibrated radiocarbon age ranges. The deposition rates used fall within the range that is considered reasonable for mires, based on recommendations in Mauquoy et al. (2002) and Goring et al. (2012). The precise details of model settings are provided in the relevant results sections. Calendar age ranges drawn from the models are reported in the text at the $2 \sigma$ confidence level.

\section{Ordination}

Multivariate statistics were limited to indirect gradient analysis through unconstrained ordination (DCA, PCA), executed using CANOCO 4.5, which combines ordination and multiple regression to solve questions about community ecology. DCA applied to untransformed percentage data for both cores revealed principal axes with lengths $<2$ s.d., and therefore PCA was selected as a more appropriate method of ordination (Ter Braak 1995; Ter Braak and Smilauer 2002). Analyses included taxa that consistently occurred at $>1 \%$ of TLP. Indicator taxa for reindeer herding, as listed by Aronsson (1991), were also included, even if these pollen types only occurred at trace values. The data were log-transformed to improve the legibility of the ordination plots.

\section{Results}

\section{Akkajärvi D (AKK D), inside the renvall}

\section{Lithostratigraphy}

The lithostratigraphy at AKK D is described in Table 1. The clay-rich basal sand is probably of glacial origin and is overlain by an uninterrupted sequence of bryophyte-rich peat.

\section{Chronology}

Radiocarbon and ${ }^{210} \mathrm{~Pb}$ dates for AKK D are presented in Tables 2 and 3. SUERC-27810 (28-27 cm) appears erroneous, as it is too old compared to the age of the bryophytes above it, and was omitted from the age-depth model. It is possible that this piece of charcoal, coming from the interface between the sandy basal sediment and the overlying peat, was deposited on the old land surface before the onset of paludification. The uppermost three ${ }^{14} \mathrm{C}$ dates returned indistinguishable calibrated age ranges (approximately cal 1650-1950) due to reversals in the IntCal13 calibration curve (Reimer et al. 2013). Bayesian age-depth modelling with Bacon operates with the prior assumption that underlying samples must be older than those above them. The inclusion of SUERC-23898 and -23899 within Bacon enables the chronology to be extended beyond the ${ }^{210} \mathrm{~Pb}$ series.

Table 1 Lithostratigraphy of the Akkajärvi D and C (AKK D, AKK C) sequences described using Troels-Smith (1955) formulae and written descriptions. Only the sections above $27 \mathrm{~cm}$ (AKK D) and from 23-0 cm (AKK C) were pollen-analysed

\begin{tabular}{|c|c|c|}
\hline Depth (cm) & Troels-Smith formula & Unit description \\
\hline \multicolumn{3}{|l|}{ AKK D } \\
\hline $23-0$ & $\begin{array}{l}\text { TSphag } 3 \mathrm{Tl}^{1} 1 \mathrm{Th}^{1}+\mathrm{Sh}+ \\
\text { Nigr } 3 \text { Strat } 0 \text { Sicc } 3 \text { Elas } 1 \text { Lim n/a }\end{array}$ & $\begin{array}{l}\text { Variously-humified yellow-brown bryophyte peat, containing abundant woody } \\
\text { rootlets and traces of herbaceous rootlets and sand }\end{array}$ \\
\hline $28-23$ & $\begin{array}{l}\text { Sh3 As1 Th+ Dl+ Anth }+ \\
\text { Nigr } 3+\text { Strat } 0 \text { Sicc } 3 \text { Elas } 0 \text { Lim } 0\end{array}$ & $\begin{array}{l}\text { Well-humified dark-brown clay-rich peat, containing traces of herbaceous rootlets. } \\
28-26 \mathrm{~cm} \text { black in colour }\end{array}$ \\
\hline $31-28$ & $\begin{array}{l}\text { Gmin } 3 \text { As1 } \\
\text { Nigr } 2 \text { Strat } 0 \text { Sicc } 3 \text { Elas } 0 \text { Lim } 0\end{array}$ & Light-grey clay-rich sand \\
\hline \multicolumn{3}{|l|}{ AKK C } \\
\hline $20-0$ & $\begin{array}{l}\mathrm{TSphag}^{1} 3 \mathrm{Th}^{1} 1 \mathrm{Tl}^{1}+\mathrm{Dl}+ \\
\text { Nigr } 1+\text { Strat } 0 \text { Sicc } 3 \text { Elas }+ \text { Lim n/a }\end{array}$ & $\begin{array}{l}\text { Poorly-humified yellow to mustard-brown Sphagnum peat, containing traces of } \\
\text { herbaceous and woody rootlets, and woody detritus }\end{array}$ \\
\hline $38-20$ & $\begin{array}{l}\text { As2 } \mathrm{Th}^{3} 2 \mathrm{Sh}+\mathrm{Tl}^{3}+ \\
\text { Nigr } 3+\text { Strat } 0 \text { Sicc } 3+\text { Elas } 0 \text { Lim } 1\end{array}$ & $\begin{array}{l}\text { Well-humified dark brown/black peat, containing increasing clay content down the } \\
\text { profile. Herbaceous stems and rootlets, plus traces of woody rootlets }\end{array}$ \\
\hline
\end{tabular}


Table 2 Radiocarbon dates and $\pm 2 \sigma$ calibrated age ranges for the Akkajärvi D and C (AKK D, AKK C) sequences, calibrated with CALIB 7.0 (Stuiver et al. 2005), operating IntCal13 (Reimer et al. 2013)

\begin{tabular}{|c|c|c|c|c|c|}
\hline Depth $(\mathrm{cm})$ & Lab code & Material & ${ }^{14} \mathrm{C}$ yr BP $( \pm 1 \sigma)$ & Cal. age $( \pm 2 \sigma)$ & $\overline{\delta^{13} \mathrm{C}(\%)}$ \\
\hline \multicolumn{6}{|l|}{ AKK D } \\
\hline $13-12$ & SUERC-23897 & Bryophyte stems and leaves & $135 \pm 30$ & AD $1672-1942$ & -27.7 \\
\hline $18-17$ & SUERC-23898 & Bryophyte leaves & $65 \pm 30$ & AD 1693-1955 & -21.5 \\
\hline $23-22$ & SUERC-23899 & Bryophyte leaves & $85 \pm 30$ & AD $1687-1926$ & -23.9 \\
\hline $28-27$ & SUERC-27810 & Charcoal & $2,360 \pm 30$ & $534-383$ вс & -26.4 \\
\hline \multicolumn{6}{|l|}{ AKK C } \\
\hline $20-19$ & SUERC-27808 & Bryophyte leaves & $105 \pm 30$ & AD 1681-1954 & -23.7 \\
\hline $25-24$ & SUERC-23894 & Peat (humic acid) & $140 \pm 30$ & AD $1669-1953$ & -27.6 \\
\hline $29-28$ & SUERC 27809 & Peat (humic acid) & $605 \pm 30$ & AD 1297-1405 & -28.0 \\
\hline $34-33$ & SUERC-23895 & Peat (humic acid) & $1,175 \pm 30$ & AD 774-964 & -27.8 \\
\hline $37-36$ & SUERC-23896 & Betula twig & $1,705 \pm 30$ & AD $225-408$ & -30.4 \\
\hline
\end{tabular}

The age-depth models produced with Clam and Bacon (Fig. 4a, b) are near identical. Preference was given to the model produced with Bacon, where the age envelope for the period of greatest interest here, the last few centuries, displays more conservative estimates. The model suggests that the top $28 \mathrm{~cm}$ of peat covers the past $\sim 200$ calendar years. This is in broad agreement with findings obtained at a variety of sites in inland northern Norrland, where the top $20-30 \mathrm{~cm}$ of profiles generally consist of poorly-humified peat not older than 200-300 years (Bradshaw and Zackrisson 1990; Aronsson 1991).

\section{Palynology}

Trampling in the annex during the extensive reindeer herding phase does not appear to have caused deleterious homogenization of the profile and its contained artefacts; the pollen spectra (Figs. 5, 6) seem to retain their stratigraphic integrity and display reasonably sharp and intelligible changes. Three LPAZs can be distinguished (Figs. 5, 6), and their key features are summarised in Table 4.

\section{Akkajärvi C (AKK C), outside the renvall}

\section{Lithostratigraphy}

The profile at AKK C consists of an uninterrupted peat deposit (Table 1). In the field, this was proven with a gouge auger to rest on a base of coarse sand at $\sim 60 \mathrm{~cm}$ depth. The lower peat unit within the monolith (below $20 \mathrm{~cm}$ ) is well-humified and contains trace amounts of clay. Poorlyhumified bryophytes form the dominant component in the topmost $20 \mathrm{~cm}$. This is broadly comparable to the lithostratigraphy recorded at AKK D (Table 1).

\section{Chronology}

Radiocarbon and ${ }^{210} \mathrm{~Pb}$ dates for AKK C are presented in Tables 2 and 3. Age-depth models produced with Clam and Bacon over the full radiocarbon-dated section of the profile $(0-37 \mathrm{~cm}$; Fig. 7) produce near-identical results and the latter (more conservative) model was selected. Both models show low accumulation rates below $\sim 25 \mathrm{~cm}$ due to compaction and humification of the peat. This is in broad agreement with patterns for other mires throughout northern Sweden (Bradshaw and Zackrisson 1990; Aronsson 1991). The Bacon age-depth model was produced covering only the pollen-analysed section $(0-23 \mathrm{~cm}$; Fig. 8). This incorporates radiocarbon dates on the humic acid fraction of a peat sample and bryophyte leaves (SUERC-23894 [25-24 cm] and $-27808[20-19 \mathrm{~cm}]$ respectively) together with ${ }^{210} \mathrm{~Pb}$ dates. The latter help overcome the difficulty of relying solely on ${ }^{14} \mathrm{C}$ dates which, when calibrated, span the problematic AD 1650-1950 section on the IntCal13 calibration curve noted earlier (Reimer et al. 2013).

\section{Palynology}

Four LPAZs can be distinguished, with AKK C-3 further divided into two subzones (Figs. 9, 10). The key features of the pollen diagram are summarized in Table 4. The pollenanalysed section at AKK C only covers the top $23 \mathrm{~cm}$ (from $\sim 1910$ onward) of a $60 \mathrm{~cm}$ long core. Palynological analysis below $23 \mathrm{~cm}$ was not undertaken as it was considered unlikely to provide the desired information on the short-lived decadal-scale occupation activity at the site, due to low temporal resolution below $\sim 25 \mathrm{~cm}$ as a result of slow peat accumulation rates and/or sediment compaction (Fig. 7). 
Table $3{ }^{210} \mathrm{~Pb}$ CRS (constant rate of supply) ages for the Akkajärvi $\mathrm{D}$ and $\mathrm{C}$ (AKK D, AKK C) sequences and their $\pm 1 \sigma$ error

\begin{tabular}{|c|c|c|}
\hline Depth $(\mathrm{cm})$ & CRS age (cal AD) & CRS age error $( \pm 1 \sigma)$ \\
\hline \multicolumn{3}{|l|}{ AKK D } \\
\hline 0 & 2008 & 0 \\
\hline $1-0$ & 2004 & 1 \\
\hline $2-1$ & 2000 & 2 \\
\hline $3-2$ & 1992 & 2 \\
\hline $4-3$ & 1987 & 2 \\
\hline $5-4$ & 1984 & 2 \\
\hline $6-5$ & 1980 & 2 \\
\hline $7-6$ & 1976 & 3 \\
\hline $8-7$ & 1968 & 3 \\
\hline $9-8$ & 1958 & 4 \\
\hline $10-9$ & 1951 & 4 \\
\hline $11-10$ & 1943 & 5 \\
\hline $12-11$ & 1932 & 6 \\
\hline $13-12$ & 1924 & 8 \\
\hline $14-13$ & 1915 & 10 \\
\hline $15-14$ & 1890 & 20 \\
\hline \multicolumn{3}{|l|}{ AKK C } \\
\hline 0 & 2008 & 0.00 \\
\hline $1-0$ & 2008 & 1.00 \\
\hline $2-1$ & 2005 & 1.09 \\
\hline $3-2$ & 2003 & 1.25 \\
\hline $4-3$ & 2001 & 1.31 \\
\hline $5-4$ & 1999 & 1.44 \\
\hline $6-5$ & 1997 & 1.49 \\
\hline $7-6$ & 1995 & 1.57 \\
\hline $8-7$ & 1991 & 1.64 \\
\hline $9-8$ & 1988 & 1.72 \\
\hline $10-9$ & 1986 & 1.77 \\
\hline $11-10$ & 1983 & 1.83 \\
\hline $12.5-11$ & 1982 & 1.88 \\
\hline $13.5-12.5$ & 1978 & 2.00 \\
\hline $15-13.5$ & 1972 & 2.17 \\
\hline $16-15$ & 1962 & 2.46 \\
\hline $17-16$ & 1958 & 2.59 \\
\hline $18-17$ & 1955 & 2.61 \\
\hline $19-18$ & 1952 & 2.75 \\
\hline $20-19$ & 1946 & 2.91 \\
\hline $21-20$ & 1938 & 2.77 \\
\hline $22-21$ & 1923 & 6.42 \\
\hline $23-22$ & 1910 & 3.41 \\
\hline $24-23$ & 1891 & 5.79 \\
\hline $25-24$ & 1864 & 19.48 \\
\hline
\end{tabular}

\section{Ordination}

The first two PCA axes of AKK D explain $61.8 \%$ of the variance in the dataset of which $36.9 \%$ is explained by axis
1 (Fig. 11). The corresponding data for AKK $\mathrm{C}$ explain $58.8 \%$ of the variance with $38.0 \%$ explained by axis 1 (Fig. 11).

\section{Discussion \\ Ordination}

The results of the PCA analyses reveal structure within the palaeo-vegetation that is significant when considering the palynological data. For this reason, these data are discussed at the outset.

The $36.9 \%$ of the PCA variance explained by axis 1 for AKK D may reflect grazing intensity. The vector for HdV113 (Sporormiella-type) extends to the positive end of this axis and correlates with several other indicators of reindeer herding, such as charcoal, Chenopodiaceae, Asteraceae, Rumex-type and Epilobium-type. Pollen samples from LPAZs AKK D-1c and -3a cluster in this section of ordination space. Taxa that correlate with the negative end of axis 1 include B. nana, Rubus chamaemorus and Apiaceae; these are considered by some to be grazing-sensitive (Scott 2001; Lendvay and Kalapos 2014; Landi et al. 2016) and may reflect periods when reindeer herding was inactive. A caveat is required, however, because Poaceae also records a negative score on axis 1. Samples from LPAZs AKK $\mathrm{D}-1 \mathrm{a}$ and $-1 \mathrm{~b}$ are associated with this area of the ordination space and therefore may reflect an absence of grazing, or at least fewer animals on site. Samples from LPAZs AKK D-2 and $-3 b$ plot towards the centre of axis 1 , and may represent vegetation communities undergoing succession following the removal of grazing pressure.

The environmental control underlying axis 2 for AKK $\mathrm{D}$, which explains $24.9 \%$ of the variance, is more difficult to explain, but it may represent a hydrological gradient. Certain taxa typically found on fen surfaces such as Cyperaceae plot towards the positive end of the axis, whilst taxa more representative of the drier soils inside the reindeer pen such as Picea and Vaccinium display negative vectors.

The $38 \%$ of the PCA variance explained by axis 1 for AKK C appears to reflect a landscape openness gradient. Vectors for Pinus and Picea point towards the negative end of the axis and seemingly represent closed canopy forest. Open ground indicators such as Poaceae, Cyperaceae and Artemisia plot towards the positive end of axis 1. Betula spp.- likely to be amongst the first trees and shrubs to invade abandoned areas-show positive axis 1 scores but have short vectors. The local abundance of Betula is currently very low and pollen accumulation rates at AKK D and $\mathrm{C}$ are generally $<1,000$ grains $\mathrm{cm}^{-2} \mathrm{yr}^{-1}$, suggesting only sparse presence of tree birch at the site (Hicks and 


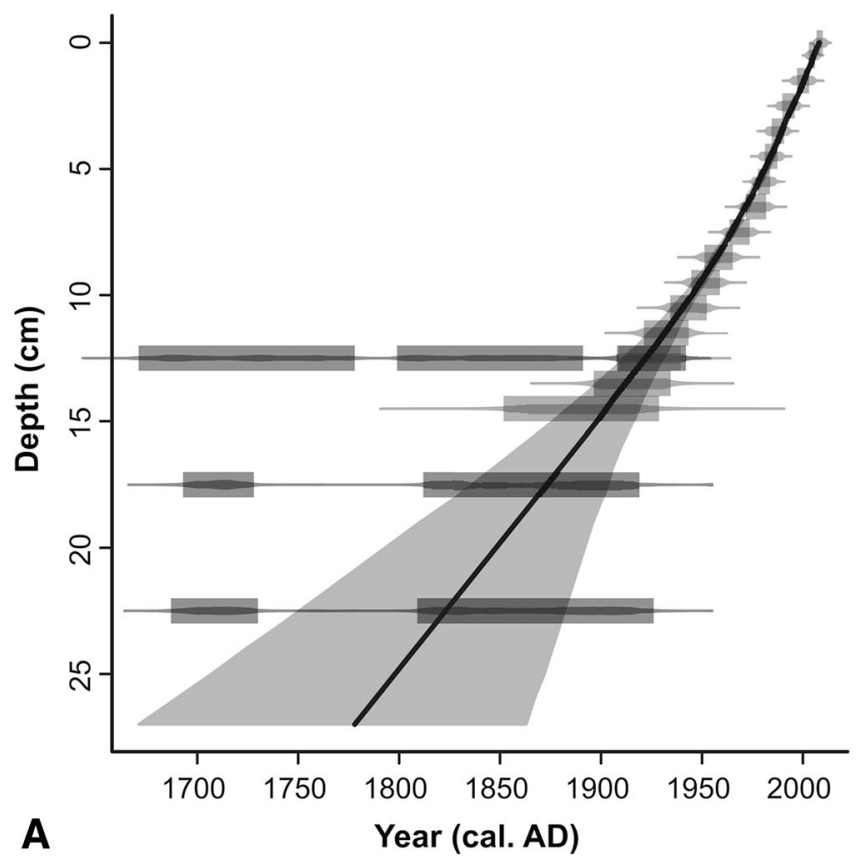

Fig. 4 Age-depth models for Akkajärvi D produced using a Clam (Blaauw 2010) and b Bacon (Blaauw and Christen 2011). Both models consider all radiocarbon measurements on bryophytes plus the ${ }^{210} \mathrm{~Pb}$ dates (Table 2,3). The basal ${ }^{14} \mathrm{C}$ date on charcoal (SUERC$27810 ; 28-27 \mathrm{~cm}$ ) was omitted because it was considered to be erroneously old (see text for further explanation). The best 'goodness
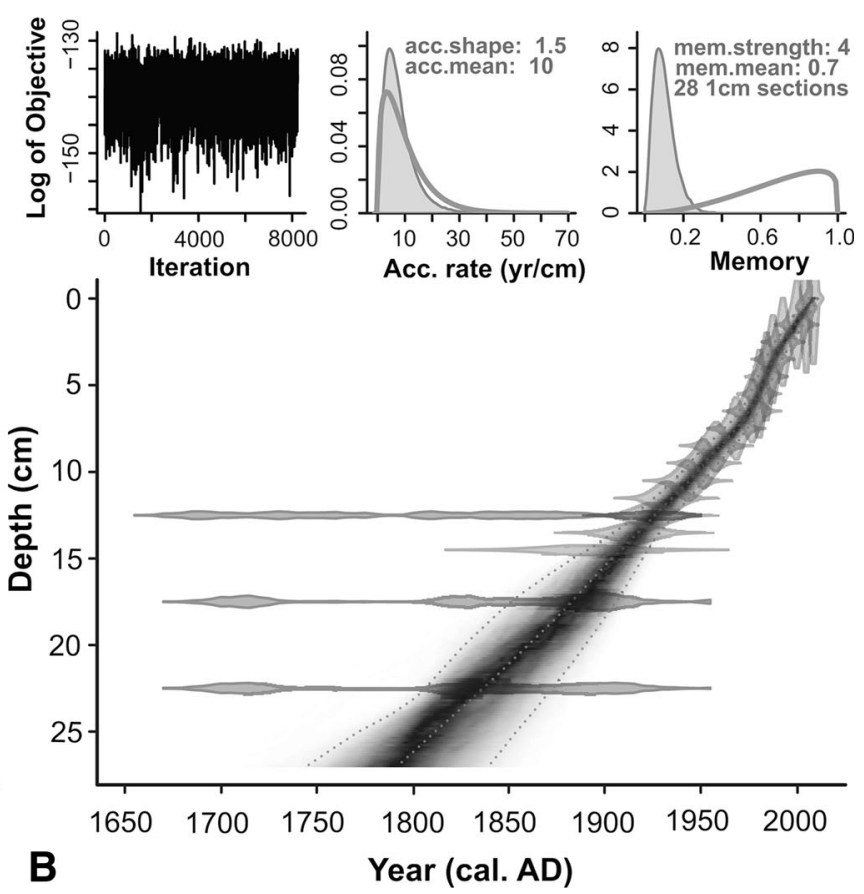

of fit' in Clam (12.15) was achieved by fitting a smoothed spline. In Bacon the following priors were set: deposition rate (acc.mean) of 10 year $\mathrm{cm}^{-1}$; accumulation shape (acc.shape) of 1.5 ; memory strength (mem.strength) of 4; memory mean (mem.mean) of 0.7. The model extrapolates to the base of the pollen-analysed sequence $(27 \mathrm{~cm})$

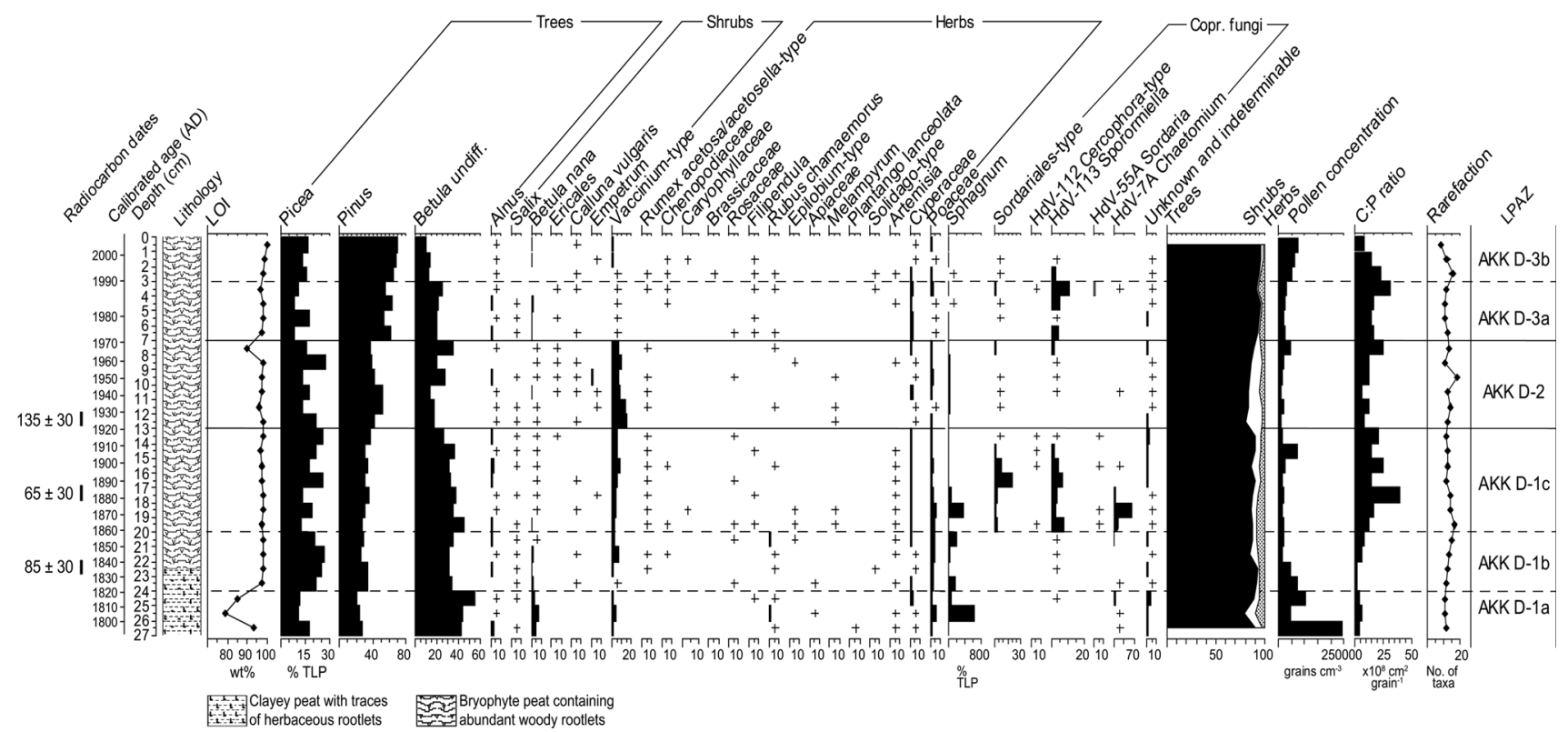

Fig. 5 Percentage pollen diagram for Akkajärvi D (AKK D) showing selected trees, shrubs, herbs, Sphagnum and coprophilous fungi. $\mathrm{X}$-axis units are \% TLP (total land pollen; minimum sum of 500) unless stated otherwise. Also included are the uncalibrated ${ }^{14} \mathrm{C}$ dates, a calibrated timescale (AD) based on the age-depth model (Fig. 4, panel B), the lithological column for the sequence, the weight percentage (wt \%) loss-on-ignition (LOI) values, the summary diagram, microscopic charcoal expressed as charcoal to pollen (C:P) ratio in $\mathrm{cm}^{2}$ grain ${ }^{-1}$ and the rarefaction index (number of taxa), with a maximum variance of \pm 2 taxa; rare types $(<1 \%)$ are indicated by a + symbol 


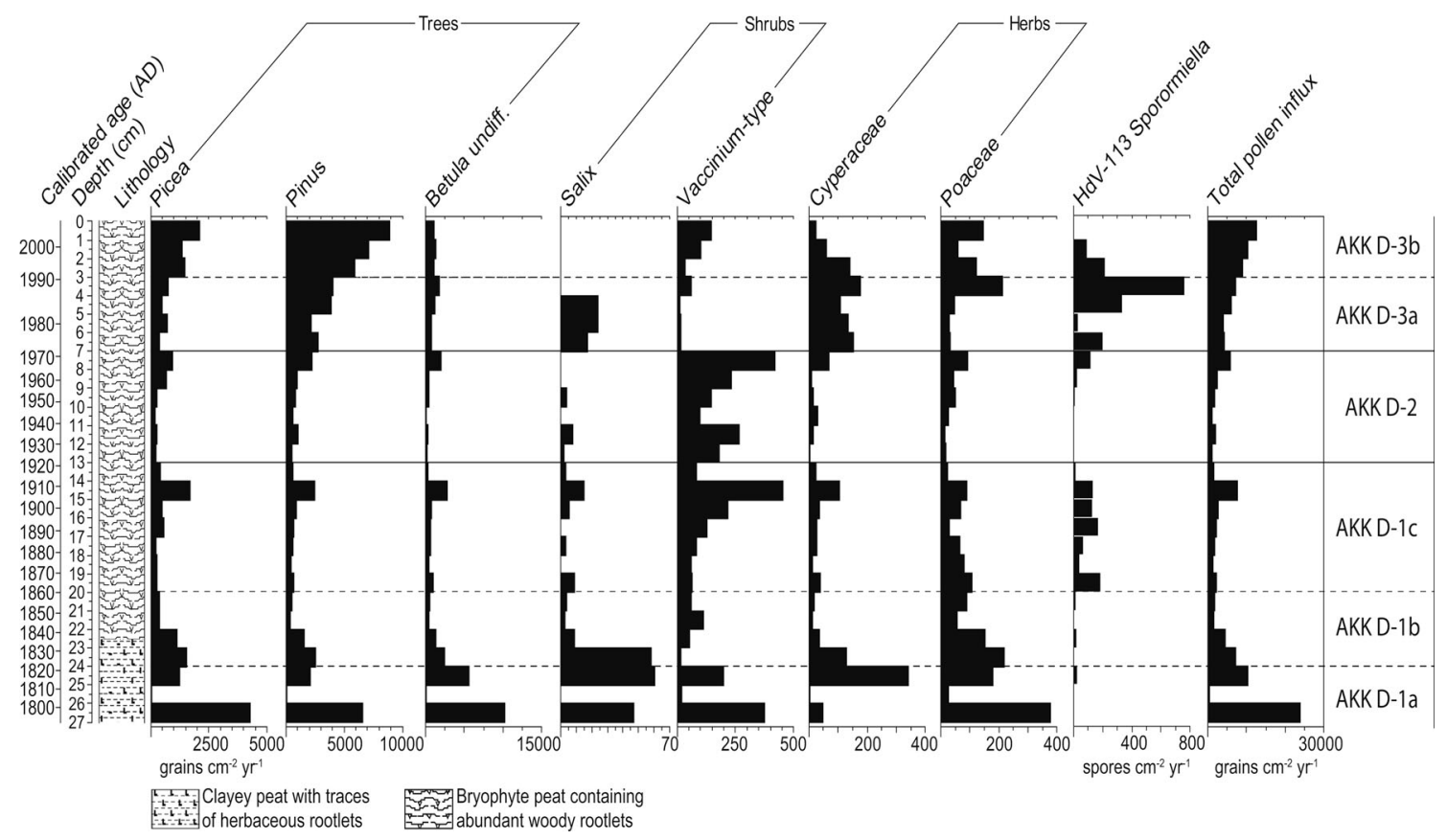

Fig. 6 Pollen accumulation rates measured in grains $\mathrm{cm}^{-2}$ year ${ }^{-1}$ for selected trees, shrubs and herbs and spore accumulation rates (spores $\mathrm{cm}^{-2} \mathrm{yr}^{-1}$ ) for Sporormiella-type at Akkajärvi D (AKK D). Note the

Hyvärinen 1999). Samples from LPAZs AKK C-1, -3a, -3b and -4 plot as a tight cluster on the negative (forested) side of axis 1, while samples from AKK C-2 sit at the positive (open landscape) end.

Axis 2 explains the remaining $20.8 \%$ of the variance and is difficult to interpret, but may reflect a hydrological gradient. The vector for Alnus, most likely A. incana based on the distribution patterns in Mossberg and Stenberg (2010), extends furthest along the negative side of axis 2. A. incana has a preference for poor, wet soils. Apiaceae displays a similar pattern. In northern Sweden this family includes taxa such as Cicuta virosa var. virosa, Angelica sylvestris, A. archangelica ssp. archangelica and Peucedanum palustre (Mossberg and Stenberg 2010), and these grow along watercourses and in damp environments. Vaccinium displays the longest vector aligned with the opposite (positive) end of axis 2. This could relate to $V$. vitis-idaea and $V$. myrtillus, both of which dominate the ground layer at the site today and are often associated with relatively dry situations; its habitats include, for example, coniferous forests, deciduous forests, heaths, pastures, protected hillsides, roadsides and crevices (Mossberg and Stenberg 2010). Alternatively, an increase in the availability of dry hummocks within the fen, where Vaccinium also tends to grow, could explain why it is positioned at the positive end of the axis. differences in scaling of the $\mathrm{x}$-axes. Also included are the uncalibrated ${ }^{14} \mathrm{C}$ dates, a calibrated timescale (AD) based on the age-depth model (Fig. 4, panel B) and the lithological column for the sequence

\section{Vegetation and land use reconstruction}

Given the similarities between AKK D and C, the palynological data from the former (within the renvall), with its superior time range, are interpreted here before drawing comparisons with AKK C. It was considered whether to draw analogies with previous studies of reindeer herding or (Mesolithic) hunter-gatherer impacts on the landscape, but such work in Fennoscandia has focused on different environmental settings, such as on high altitude alpine woodlands and treeless alpine heaths (Salmonsson 2003; Karlsson et al. 2007; Staland et al. 2011; Bergman et al. 2013; Möller et al. 2013) or on coastal areas (Hörnberg et al. 2005). Extensive logging from the end of the 1800s has destroyed archaeological evidence of both Sami reindeer herding and agricultural settlement (Östlund and Bergman 2006). Modern analogue studies of the impacts of reindeer trampling and grazing on the vegetation mainly consider the effects on lichen abundance in winter grazing areas on alpine tundras and in woodlands (Väre et al. 1995; Suominen and Olofsson 2000). The renvall at Akkajärvi, however, was not used for grazing but was strictly employed for gathering of reindeer in summer, first for milking and later for calfmarking. 
Table 4 Description of the LPAZs at Akkajärvi D and C based on percentage and PAR diagrams, including loss-on-ignition (LOI), the charcoal to pollen ratio $(\mathrm{C}: \mathrm{P})$ and pollen concentrations

\begin{tabular}{|c|c|c|c|}
\hline $\begin{array}{l}\text { LPAZ } \\
\text { (AKK) }\end{array}$ & $\begin{array}{l}\text { Depth } \\
(\mathrm{cm})\end{array}$ & $\begin{array}{l}\text { Cal age } \\
\text { (AD) }\end{array}$ & Diagnostic pollen and spore characteristics based on percentage and PAR diagrams \\
\hline D-3b & $3-0$ & 1990-2009 & $\begin{array}{l}\text { Pinus and Picea increase (both in relative and absolute terms); Vaccinium-type recovers; Cyperaceae are } \\
\text { reduced, Poaceae retain near-constant values, no other herbaceous taxa present at } 1-0 \mathrm{~cm} \text {; C:P falls } \\
\text { throughout, rarefaction values decrease from } 15-8 \text { taxa and LOI increases to } 99 \% \text {; pollen influx and } \\
\text { concentrations further increase }\end{array}$ \\
\hline D-3a & $7-3$ & $1970-1990$ & $\begin{array}{l}\text { Pinus gains dominance }(38-52 \%) \text {; Vaccinium-type reduced to traces; Cyperaceae increase by } \\
\sim 200 \text { grains } \mathrm{cm}^{-2} \mathrm{yr}^{-1} \text {, while Poaceae are mostly reduced to trace values and traces of Chenopodiaceae } \\
\text { and Solidago-type re-emerge at 5-3 cm; Sporormiella-type (HdV-113); C:P increases and rarefaction } \\
\text { values fluctuate between } 11 \text { and } 13 \mathrm{taxa} \text {; pollen concentrations and influx increase somewhat }\end{array}$ \\
\hline D-2 & $13-7$ & $1920-1970$ & $\begin{array}{l}\text { PAR of all tree taxa increase; Vaccinium-type increases and pollen of other ericaceous shrubs (i.e. Calluna } \\
\text { Empetrum) becomes more common; Cyperaceae are regularly reduced to trace values; Cyperaceae } \\
\text { mostly reduced to trace values. Fewer occurrences of herbaceous taxa, most notably Artemisia; } \\
\text { frequencies of coprophilous fungal spores are reduced to trace values with intermittent presence; C:P } \\
\text { reduced, rarefaction values fluctuate between } 11 \text { and } 14 \text { taxa, with an excursion to } 18 \text { taxa at } 10-9 \mathrm{~cm} \\
\text { and the LOI dips to } 90 \% \text { at } 8-7 \mathrm{~cm}\end{array}$ \\
\hline D-1c & $20-13$ & $1860-1920$ & $\begin{array}{l}\text { Picea and Pinus increase, which is balanced out by a decline in Betula undiff.; B. nana reduced to traces as } \\
\text { Vaccinium-type increases; Poaceae (PAR) fluctuates and traces of a greater range of herbs (e.g. } \\
\text { Caryophyllaceae and Melampyrum-type) first appear, whilst Apiaceae and Solidago-type disappear; } \\
\text { coprophilous fungal spores of Sordariales, Sporormiella-type (HdV-113) and Chaetomium-type (HdV-7a) } \\
\text { become abundant; rarefaction increases to } 17 \text { but then decreases to } 12 \text { taxa and LOI remains high and } \\
\text { stable }(\sim 98 \%)\end{array}$ \\
\hline $\mathrm{D}-1 \mathrm{~b}$ & $24-20$ & $1825-1860$ & $\begin{array}{l}\text { All trees decline (PAR) while Vaccinium-type increases; Cyperaceae and Poaceae decrease (PAR), traces } \\
\text { of } R \text {. acetosalacetosella-type, Chenopodiaceae, Epilobium-type and Solidago-type appear for the first } \\
\text { time; traces of Sporormiella-type (HdV-113) present; C:P increases somewhat, rarefaction values } \\
\text { increase from } 12 \text { to } 15 \text { taxa, LOI high and stable }(\sim 98 \%) \text {; pollen influx and concentrations decline }\end{array}$ \\
\hline D-1a & $\begin{array}{l}\text { Up to } \\
24\end{array}$ & Up to 1825 & $\begin{array}{l}\text { Betula undiff. dominant ( }>40 \% \text { TLP) with Picea and Pinus contributing a further } \sim 40 \% \text {; prominent non- } \\
\text { arboreal taxa include B. nana, Vaccinium-type, Cyperaceae and Poaceae; rarefaction consequently low } \\
\text { (10-12 taxa), as are C:P and LOI shows a mid-zone decline to } 79 \%\end{array}$ \\
\hline $\mathrm{C}-4$ & $4-0$ & $2000-2009$ & $\begin{array}{l}\text { Pinus rises to dominate ( }>60 \%) \text {; B. nana reduced; Many herbaceous taxa disappear and traces of } R \text {. } \\
\text { acetosa/acetosella-type, Chenopodiaceae, Spergula, Rosaceae and Rubus chamaemorus are } \\
\text { discontinuous; coprophilous fungal spores become infrequent; C:P reduced and rarefaction values } \\
\text { decrease (9-14 taxa) }\end{array}$ \\
\hline $\mathrm{C}-3 \mathrm{~b}$ & $7-4$ & $1995-2000$ & $\begin{array}{l}\text { All trees are reduced while the influx and percentages of } B \text {. nana and Vaccinium-type become slightly } \\
\text { elevated; Herbaceous flora diversify (e.g. Epilobium-type and Plantago major are added), Cyperaceae are } \\
\text { reduced traces and Poaceae increases; coprophilous fungal diversify and increase; C:P increases and } \\
\text { rarefaction peaks mid-zone at } 18 \text { taxa }\end{array}$ \\
\hline C-3a & $14-7$ & 1975-1995 & $\begin{array}{l}\text { Pinus and Picea increase; Fewer herbaceous taxa occur, and frequencies of Poaceae and Cyperaceae are } \\
\text { significantly reduced, while Ranunculus acris-type and Galium-type appear; coprophilous fungal spores } \\
\text { become rare, while Sphagnum peaks. C:P is reduced, rarefaction values decrease from } 17 \text { to } 12\end{array}$ \\
\hline $\mathrm{C}-2$ & $20-14$ & 1945-1975 & $\begin{array}{l}\text { Reductions in Pinus and Picea, Betula now dominates; Vaccinium-type peaks then falls; Poaceae increase } \\
\text { and many herbs appear at trace values (R. acetosa/acetosella-type, Chenopodiaceae, Brassicaceae, } \\
\text { Epilobium-type, Melampyrum, Plantago lanceolata, Achillea-type, Artemisia). Sporormiella-type (HdV } \\
113 \text { ) elevated, traces of Sordariales, Sordaria (HdV-55A) and Chaetomium (HdV-7A). C:P elevated, } \\
\text { rarefaction increases (13-20 taxa) and LOI decreases to } 95 \% \text { at } 15-14 \mathrm{~cm}\end{array}$ \\
\hline $\mathrm{C}-1$ & $\begin{array}{l}\text { Up to } \\
20\end{array}$ & Up to 1945 & $\begin{array}{l}\text { Pinus, Picea and Betula undiff. dominant; } \text { B. nana and Vaccinium-type low; limited herbaceous pollen } \\
\text { (notably } R \text {. chamaemorus, Cyperaceae and Poaceae with traces of Solidago-type and Artemisia at } \\
21-20 \mathrm{~cm} \text { ). Traces of Sordariales, Sporormiella-type [HdV-113] and Chaetomium }[\mathrm{HdV}-7 \mathrm{~A}] \text {; C:P low, } \\
\text { rarefaction at } 12-13 \text { taxa }\end{array}$ \\
\hline
\end{tabular}

\section{Natural conditions in the absence of human impact} $(\sim 1795-1825)$

High arboreal pollen frequencies in AKK D-1a $(>80 \%$ Picea, Pinus and Betula undiff.), a lack of palynological 'indicators' for reindeer herding (Aronsson 1991), the nearabsence of coprophilous fungal spores and low charcoal to pollen $(\mathrm{C}: \mathrm{P})$ values combine to suggest that the renvall was not in use during this period. LOI values are very high compared to the succeeding LPAZs, implying that soils 

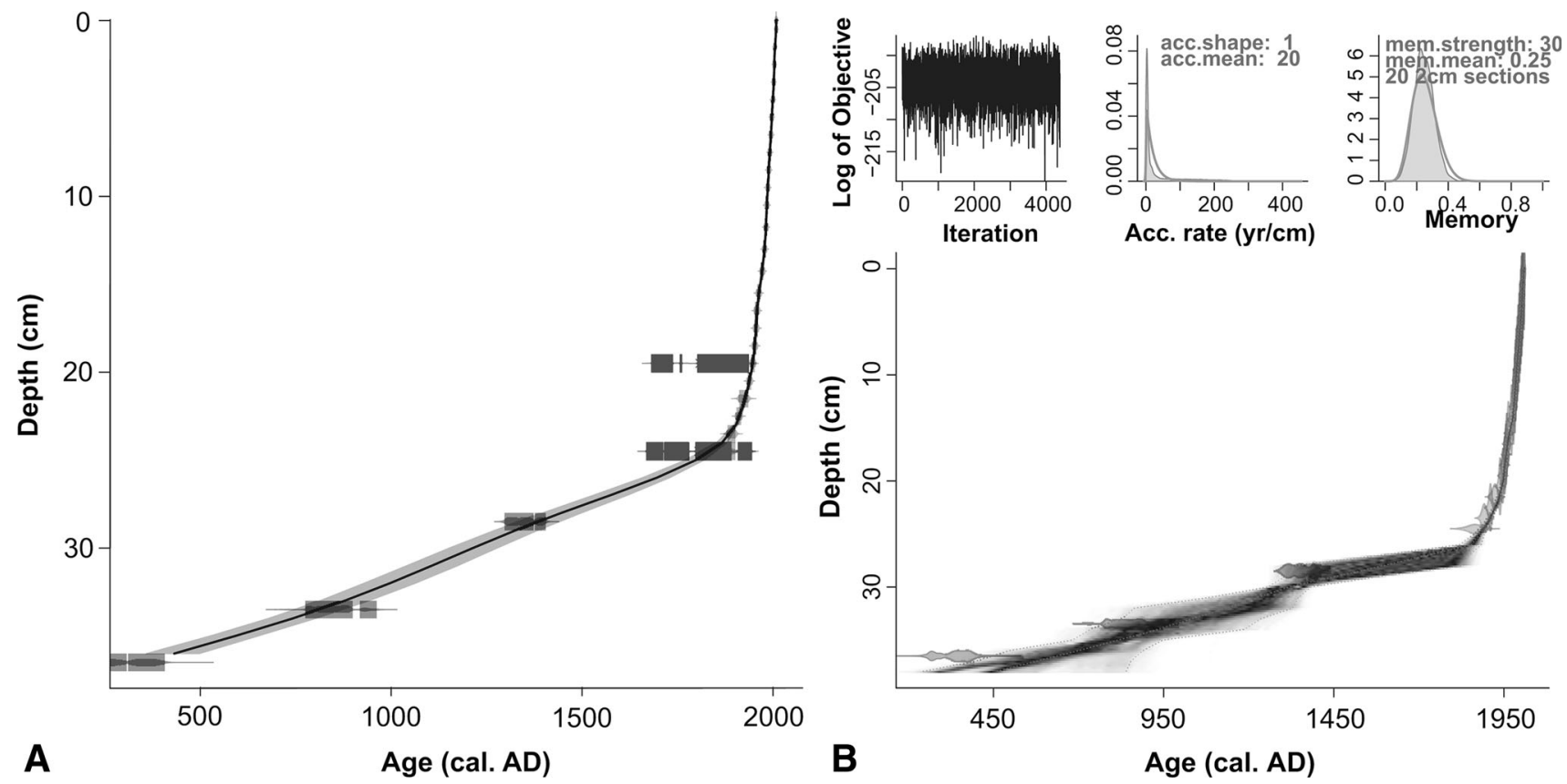

Fig. 7 Age-depth models for Akkajärvi C produced using a Clam (Blaauw 2010); b Bacon (Blaauw and Christen 2011). Both models consider ${ }^{14} \mathrm{C}$ measurements on peat samples (humic acid fraction) at 29-28 and 34-33 cm (SUERC-27809 and 23895 respectively), a Betula twig at $37-36 \mathrm{~cm}$ (SUERC-23896), plus the ${ }^{210} \mathrm{~Pb}$ dates (Tables 2, 3). Radiocarbon dates on material at 25-24 cm (humic acid fraction of peat; SUERC-23894) and at 20-19 cm (bryophyte leaves; SUERC-27808) are marked as outliers because more accurate ${ }^{210} \mathrm{~Pb}$

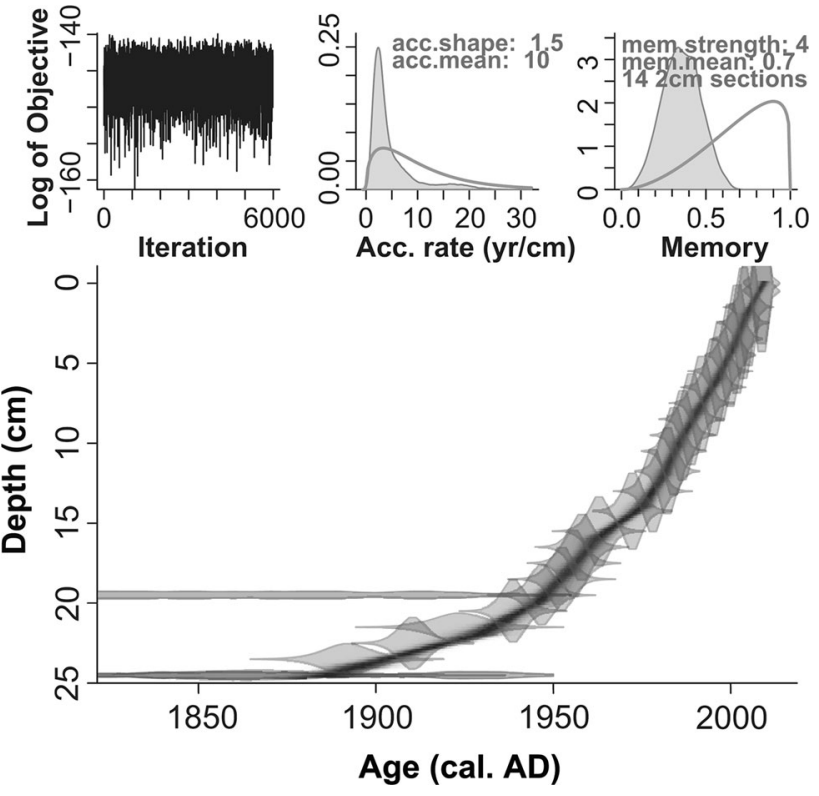

Fig. 8 Bacon age-depth model covering the pollen-analysed sequence of Akkajärvi C (AKK C; 0-23 cm). Model priors were set as follows: deposition rate (acc.mean) $=10 \mathrm{yr} \mathrm{cm}^{-1}$; accumulation shape $($ acc.shape $)=1.5 ;$ memory strength $($ mem.strength $)=4$; memory mean (mem.mean) $=0.7$ dates were also available for these levels. The best goodness of fit in Clam (18.32) was achieved by fitting a smoothed spline, whereas in Bacon a prior deposition rate (acc.mean) set to $20 \mathrm{yr} \mathrm{cm}^{-1}$, an accumulation shape (acc.shape) of 1, a memory strength (mem.strength) of 10 and a memory mean (mem.mean) of 0.25 , provided the best fit. A separate model was produced with Bacon for the pollen analysed section only (Fig. 8)

were stable. The elevated pollen influx values in the basal pollen sample seemingly reflect the dominance of high pollen producing trees such as Pinus and Betula (Hicks and Hyvärinen 1999).

Initiation of intensive clearance and gathering of animals $(\sim 1825-1860)$

In AKK D-1b, low levels of HdV-113 (Sporormiella-type) spores and the appearance of traces of Rumex-type, Chenopodiaceae, Epilobium-type and Solidago-type pollen suggest that some level of disturbance occurred during this period. Pollen accumulation rates (PARs) for Pinus and Betula also drop below the threshold for local presence, $<2,000$ and $<1,500$ grains $\mathrm{cm}^{-2} \mathrm{yr}^{-1}$ respectively in northern Fennoscandian boreal forests (Hicks and Hyvärinen 1999) and C:P values increase somewhat, although not far beyond the values recorded for AKK D-1a. The former may be related to some initial clearance within the renvall in preparation for reindeer herding, and the increase in C:P could be due to the input of microscopic charcoal produced by smudge and/or domestic fires. 


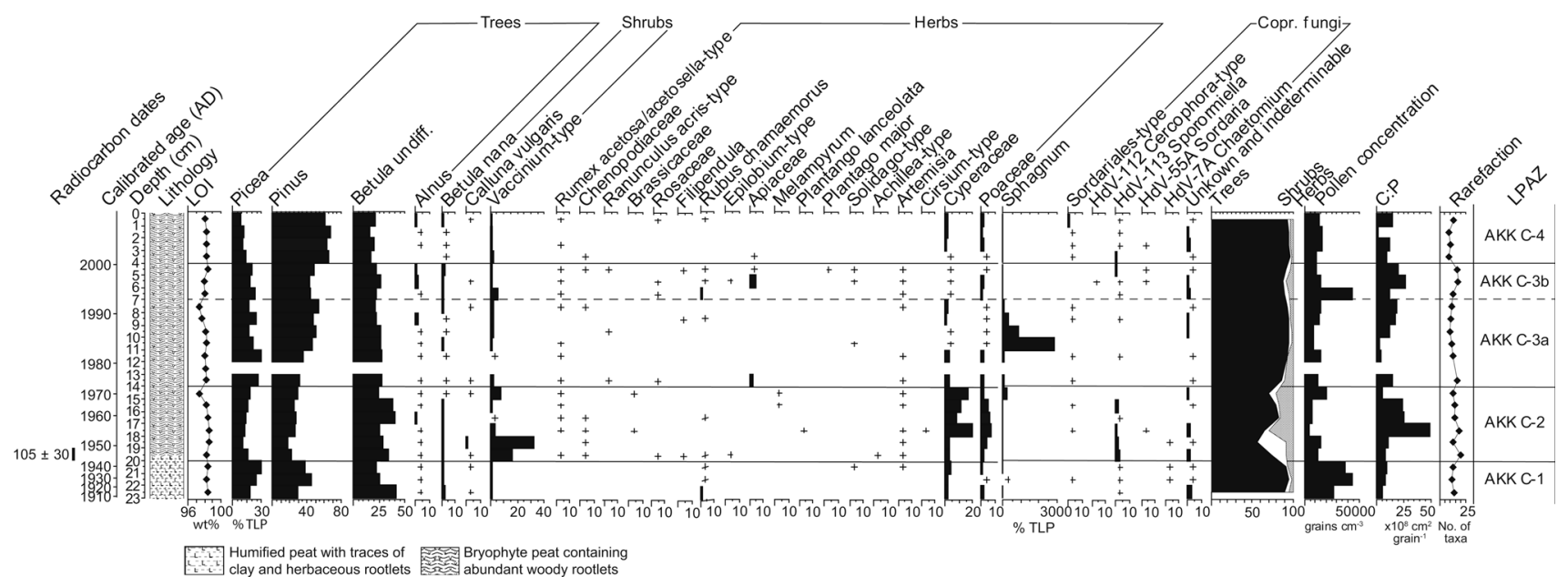

Fig. 9 Percentage pollen diagram for Akkajärvi C (AKK C) showing selected trees, shrubs, herbs, Sphagnum and coprophilous fungi. Calculations are based on a minimum total land pollen (TLP) sum of 500. Also included are the uncalibrated ${ }^{14} \mathrm{C}$ dates, calibrated ages (AD) based on the age-depth model (Fig. 8), the lithological column for the sequence, the weight percentage (wt \%) loss on ignition (LOI) values, the summary diagram, microscopic charcoal expressed as charcoal to pollen (C:P) ratio in $\mathrm{cm}^{2}$ grain ${ }^{-1}$ and the rarefaction index (number of taxa), with a maximum variance of \pm 1 taxa; rare types $(<1 \%)$ are indicated by a + symbol. Data are unavailable for $13-12 \mathrm{~cm}$ due to the low pollen concentration in this sample

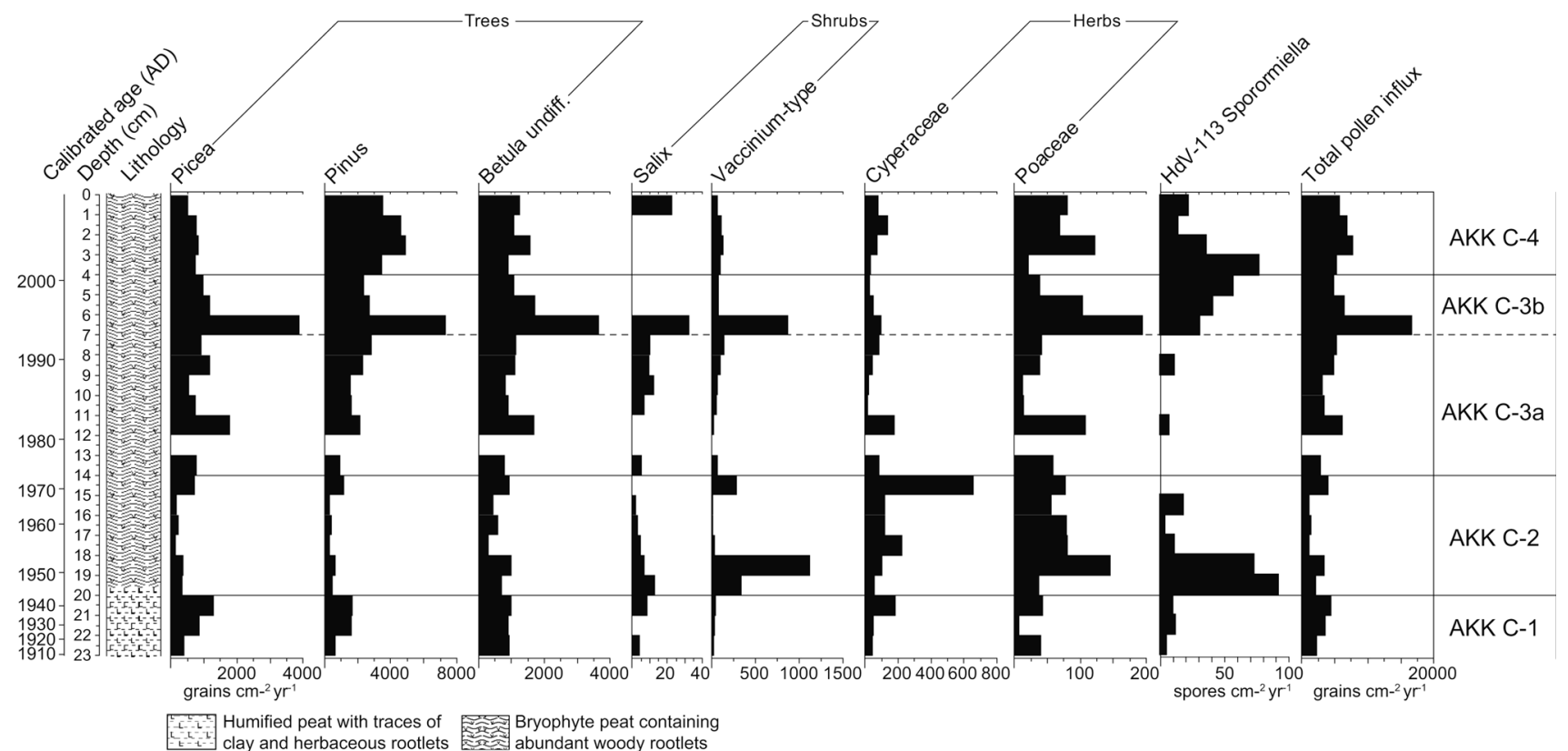

Fig. 10 Pollen accumulation rates measured in grains $\mathrm{cm}^{-2}$ year ${ }^{-1}$ for selected trees, shrubs and herbs, and spore accumulation rates (spores $\mathrm{cm}^{-2} \mathrm{yr}^{-1}$ ) for Sporormiella-type, at Akkajärvi C (AKK C). Note the differences in scaling of the $\mathrm{x}$-axes. Also included are the uncalibrated ${ }^{14} \mathrm{C}$ dates, a calibrated timescale (AD) based on the agedepth model (Fig. 8) and the lithological column for the sequence. Data for $13-12 \mathrm{~cm}$ are unavailable due to the low pollen concentration in this sample

\section{Intensive reindeer herding ( 1860-1920)}

High frequencies of coprophilous fungal spores (Sporormiella-type, Sordariales-type and Chaetomium-type) in AKK D-1c, together with elevated C:P, provide strong evidence for a period of reindeer herding activity with smudge fires at the site. A slight increase in Cyperaceae is also apparent. This may reflect increased light levels at the forest floor following clearance for the renvall. Alternatively, growth of sedges may have been promoted by the creation of small pools on the fen surface through the cutting of peat to fuel the smudge fires. Several open 
Fig. 11 PCA scatterplots for Akkajärvi D (panels A1, A2) and Akkajärvi C (panels B1, B2). A1 and B1 depict palynomorphs and LOI. A2 and B2 display sample scores for the pollen assemblages and are grouped according to LPAZs

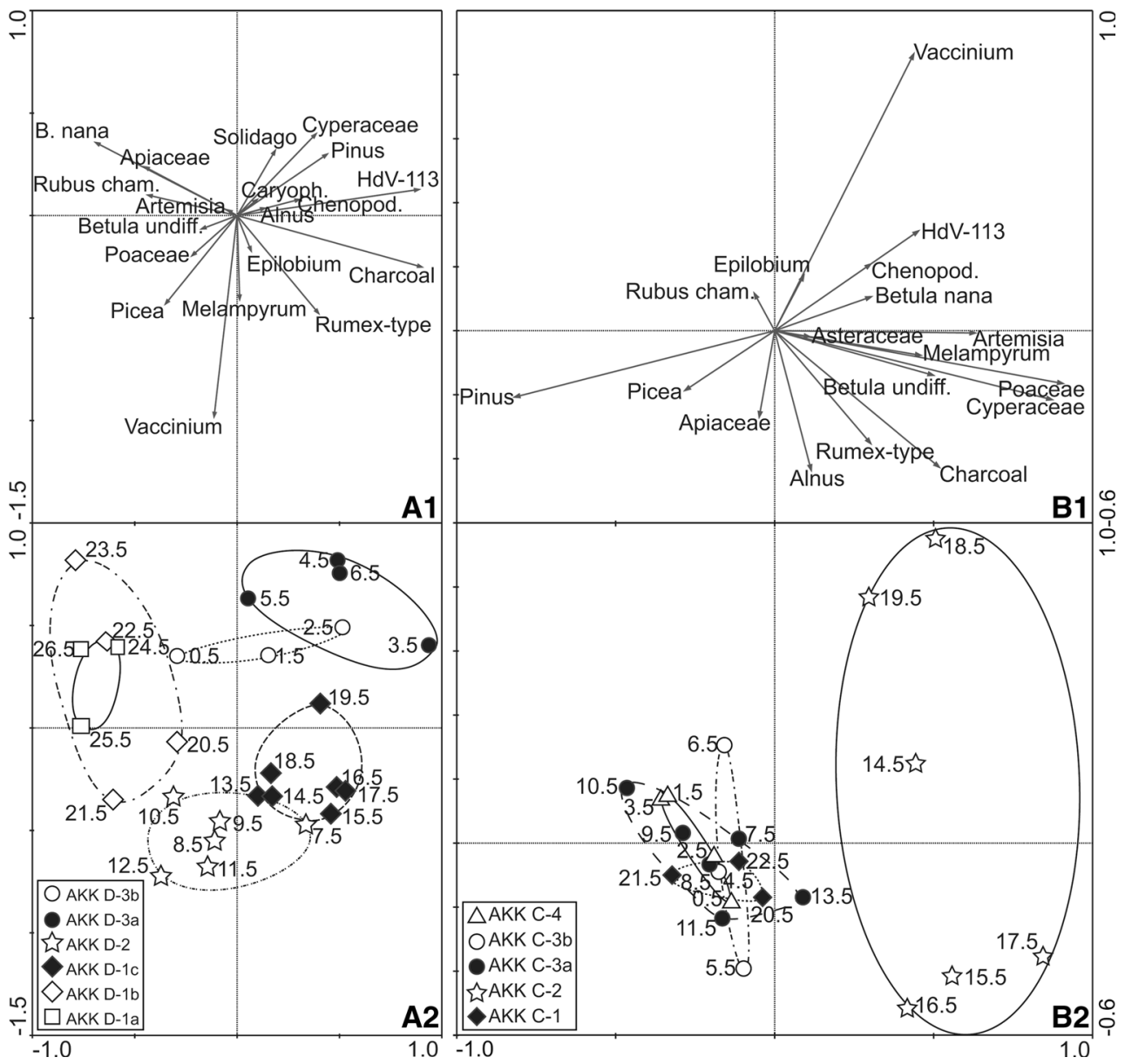

landscape indicators are recorded, such as Chenopodiaceae, Caryophyllaceae, Epilobium-type, Melampyrum and Rosaceae (Behre 1981; Edwards and MacDonald 1991).

\section{First abandonment of the renvall ( 1920-1970)}

The most obvious changes in AKK D-2 are an increase in the abundance of Vaccinium alongside a more continuous presence of Calluna and Empetrum. Following an initial fall, the PAR of Picea rises. Pinus and Betula increase throughout the zone to levels indicating a local presence. All of these changes are likely to be related to a succession towards boreal forest following abandonment, generally starting with a stage dominated by ericaceous heaths, followed by the rise to dominance of Betula, Pinus and finally Picea. Poaceae do not disappear completely from this LPAZ and traces of Rumex-type, Artemisia and Epilobiumtype pollen remain, suggesting that the canopy was not completely closed. Part of the increase in Pinus may derive from the introduction of forest management and sustainable forestry, which began in 1906 (Östlund 1995).

The continued but reduced presence of Cyperaceaemost obvious in the PAR diagram (Fig. 6) — could relate to the replacement of sedges by ericaceous heaths within the renvall as recovery of the natural forest vegetation progressed, or to the limited creation of new damp habitats due to either the cessation of peat cutting, or the development of a warmer and drier climate during the 20th century (Seppä et al. 2009; St. Amour et al. 2010; Lindholm et al. 2012). C:P is reduced compared to the previous LPAZ, which could reflect the absence of smudge fires. A dip in LOI at AKK D at 8-7 cm ( 1969), just below the AKK D-2/3a boundary, may be related to a very brief period of increased soil erosion as the renvall was expanded with the addition of the phase 2 annex and hut (Fig. 2; Aronsson 1991).

\section{Re-use of the renvall for extensive reindeer herding ( 1970-1990)}

For AKK D-3a, the similar composition of shrubs (including heaths) and herbs when compared to AKK D-1c (Figs. 5, 6), as well as a rise in Sporormiella-type spores and $\mathrm{C}: \mathrm{P}$, appears to reflect the reintroduction of reindeer herding. This event is dated to $\sim 1970$, and the timing closely fits with the oral history for the site. The abrupt 
reduction of Vaccinium-type pollen to trace values suggests that it may have been severely affected by grazing pressure such as defoliation, trampling and fertilization (Sørensen et al. 2009) within the renvall. The relatively small increase in Poaceae and absence of several herbaceous taxa (Caryophyllaceae, Epilobium-type and $\mathrm{Me}$ lampyrum) that were recorded during the previous (intensive) stage of use for the pen (AKK D-1c), as well as a discontinuous presence of Artemisia and a lack of increase in community diversity, all imply that the impact of reindeer herding during this second, extensive phase was relatively weak. This can perhaps be explained by the change in function for the renvall-now used for calf marking rather than milking-which required the herd to be on site for a shorter period (up to $24 \mathrm{~h}$ ), compared to the several consecutive weeks required for reindeer milking.

\section{Recent abandonment ( 1990-present)}

LPAZ AKK D-3b reflects the most recent phase of abandonment, which the age-depth model estimates to have started around 1990. A recovery of selected trees and shrubs (Pinus, Picea and Vaccinium-type) is visible in the influx data, together with a reduction in Cyperaceae, and an overall decline in community diversity as herbaceous taxa indicative of landscape openness disappear. This explains the central position of pollen assemblages from this LPAZ along axis 1 in the PCA (Fig. 11). The recovery was relatively rapid compared to AKK D-2, probably because the impact of reindeer herding during AKK D-3a was not as intense or sustained as that of the earlier phase. The timing of the palynological signal for abandonment is in good agreement with the observation that the renvall was still in use during the 1980s. The elevated total pollen influx values seen in this LPAZ may be explained by the regeneration of trees, notably Pinus and, to a lesser extent, Picea. There is a reduction in C:P and this would be expected in the absence of smudge fires.

\section{Comparison of profiles}

The correspondence between the LPAZs for AKK C (fen) and AKK D (annex) is summarized in Fig. 12. The latter profile covers a longer period of time, $\sim 200 \mathrm{cal}$ yr compared to 100 years for the fen, with similar vegetational changes displayed at both locations during the period when the cores overlap chronologically. A notable vegetation change recorded in both sequences is the regeneration of heaths, particularly Vaccinium (Figs. 5, 6, 9, 10) from the start of the first abandonment phase, beginning $\sim 1920$. This seems likely to reflect a recovery of Vacciniumdominated plant communities within the abandoned renvall, perhaps with additional contributions of pollen resulting from the local expansion of crowberry over dry hummocks on the fen in response to the warmer and drier climate of the modern period. Herbaceous pollen is minimal throughout both profiles. Pollen of apophytes (taxa that are native but are favoured and spread, directly or indirectly by cultural activity and colonize newly established biotopes; Behre 1988) linked to Sami activity is registered in both profiles, but only at trace values, making the palynological signal for reindeer herding very difficult to distinguish from the background pollen rain produced by the surrounding boreal forest vegetation. This signal weakens with increasing distance from the locus of human and animal activity, as evidenced by the reduced frequency of herbaceous pollen types recorded at AKK C compared to AKK D during the phases when the renvall was in use. A stronger signal for herding is providing through changes in microscopic charcoal-which increases in abundance during the periods when the renvall was active, probably as a consequence of the lighting of smudge fires-and the coprophilous fungal spore record. The latter is discussed in further detail below.

\section{Coprophilous fungal spores as indicators of land use}

Overall, the palynological records obtained from within the annex and on the fen display broadly similar patterns (Figs. 5, 9) which match chronologically (Fig. 12). In both sequences the herbaceous pollen content is minimal, meaning that the detection of past human impact on the environment in this context depends heavily on the patterns shown by the coprophilous fungal spores within the renvall annex (AKK D). A peculiarity arises in that the coprophilous fungal spore signal from the fen (AKK C) is out of phase with that from the renvall. High spore frequencies are recorded at AKK D during the two reindeer herding phases (LPAZs AKK D-1c and AKK D-3a). At the same time, percentages of fungal spores are suppressed on the fen (LPAZs AKK C-1 and 3a). Conversely, levels of Sporormiella-type (HdV-113) are elevated on the fen during presumed periods of abandonment (LPAZs AKK C-2, -3b and -4) at a time when only traces of these spores are recorded inside the reindeer pen (LPAZs AKK D-2 and D-3b).

This pattern might be explained if the chronologies for the profiles are also slightly offset, yet there is no reason to believe that the age-depth model for either of the two sequences, which is largely based on ${ }^{210} \mathrm{~Pb}$ dating with very small associated errors, is inaccurate. Both AKK D and AKK C display apparent stratigraphic integrity and the palaeoecological signal for reindeer herding and abandonment at AKK D closely matches the oral history of the site.

The spatial patterns presented in the coprophilous fungal spore data could reflect the use by reindeer of separate 
Fig. 12 Comparison of the summary pollen diagrams for Akkajärvi D (AKK D) and Akkajärvi C (AKK C).

Correlation between the LPAZs is indicated by dashed lines

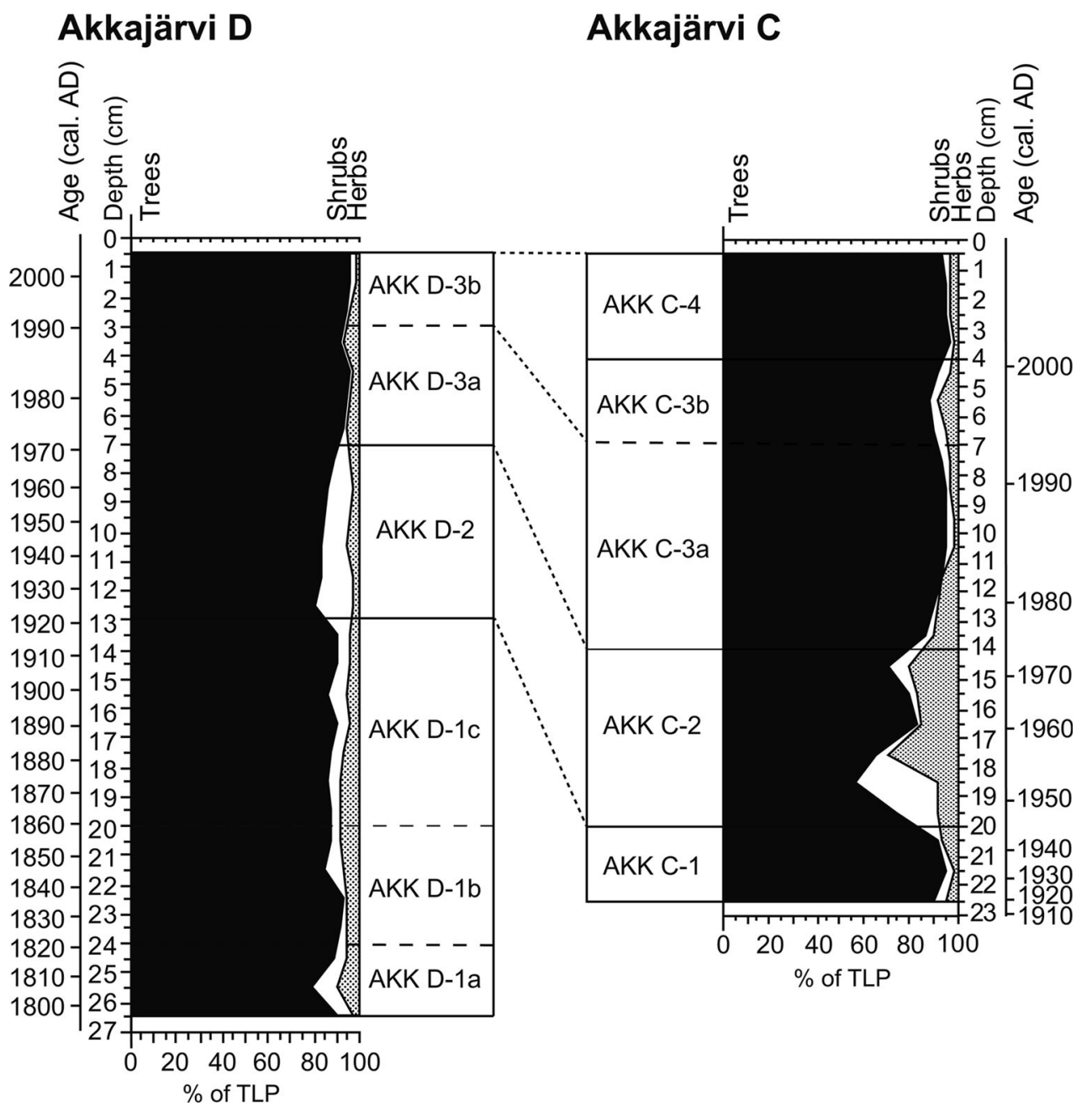

areas at Akkajärvi at different times. Taphonomic studies demonstrate that coprophilous fungal spores do not travel far from their source (Raper and Bush 2009), with dispersal often limited to $\leq 2.5 \mathrm{~m}$ from the fruiting body (Ingold 1971; Yafetto et al. 2008). Spores released from fungi growing on dung within the renvall (AKK D) might not arrive at AKK C, $15 \mathrm{~m}$ from the annex boundary. This would account for the strong fungal spore signature within the reindeer pen, and the weak to absent signal from the fen, during periods when the renvall was in use.

More puzzling are the elevated frequencies of fungal spores recorded on the mire (AKK C) and the subdued percentages of spores deposited in the annex (AKK D), during periods when the renvall was not in use. The creation of this pattern would require a situation where reindeer regularly returned to graze at the mire but had little, if any, access to the interior of the pen. The mire at Akkajärvi is situated within the wider pasturing grounds for reindeer in this region, yet this raises the additional question as to why the frequencies of coprophilous fungal spores do not remain more constant throughout the mire profile, unless animals were kept away from this area when the pen was in use. Wood and Wilmshurst (2012) argue that the interpretation of records for coprophilous fungal spores (specifically Sporormiella-type) from wetlands is far from straightforward, and that spore abundances can fluctuate in response to changes in mire surface hydrology.

It would seem that coprophilous fungal spores are a reliable indicator of reindeer herding activity when studied within a known locus of activity, provided that there is an awareness of the fact that the signal can weaken significantly over short distances from the gathering locations. At AKK D, within the renvall annex, the record for coprophilous fungi satisfactorily matches the oral history of Sami activity at the site, while the impacts on the vegetation as revealed through the pollen record appear to be minimal, with the signal from 'indicator' taxa arising from disturbance often masked by the pollen from high-pollen producing trees such as Betula and Pinus. In such cases, the analysis of coprophilous fungi becomes an important means for establishing the local ('on-site') presence of herbivores. 
Establishing an empirical relationship between herbivores and the abundance of coprophilous fungal spores in the fossil record is proving elusive, but it is generally considered that greater numbers of animals will produce larger quantities of dung and, therefore, higher numbers of spores (Baker et al. 2013). Variations in spore numbers are therefore typically interpreted as representing changes in the size of herbivore populations (Davis 1987; van Geel et al. 2003; Davis and Shafer 2006), with Sporormiellatype (HdV-113) considered to be the most useful indicator of herbivore presence (Davis and Shafer 2006; Raper and Bush 2009; Feranec et al. 2011). It should be noted that the characteristically large herds present during the extensive reindeer herding phase at Akkajärvi between 1970 and 1990 resulted in similar frequencies of coprophilous fungal spores being recorded when compared with those during the intensive reindeer herding phase $(\sim 1860-1920)$ with its much smaller-sized herds. The absence or limited presence of Sordariales-type and Cercophora-type (HdV112) spores during the latter phase formed the main difference in the coprophilous fungal spore signature between the two periods of on-site activity (Fig. 5). During the intensive phase, reindeer would be present at the renvall for milking purposes over several weeks during the summer months, whereas during the extensive phase it was used for calf marking over a period of a day at most. This could imply, unsurprisingly, that the abundance of certain coprophilous fungi may not only be controlled by herbivore density, but also by the duration of the presence of the animals on the site.

\section{Conclusions}

High resolution palynological analyses, combined with Bayesian age-depth modelling of ${ }^{210} \mathrm{~Pb}$ and ${ }^{14} \mathrm{C}$ dates, has allowed the identification of two multi-decadal periods of renvall use in northern Sweden. The first period was dated to $\sim 1860-1920$, a time when intensive reindeer herding was still practised, and the second ( 1970-1990) followed the introduction of extensive herding practices. The timing obtained for these two phases broadly fits oral histories for the site that suggest abandonment around 1910-1920, followed by re-use around 1960-1970, and a subsequent abandonment during the late 1980s. The impacts of reindeer herding on vegetation across the site appear slight in the pollen record. The signal for activity is characterised by trace values of pollen of Epilobium-type and various ruderal plants such as Rumex-type, Chenopodiaceae, Caryophyllaceae and Melampyrum, and abandonment is indicated by successive increases in Poaceae, ericaceous heaths, particularly Vaccinium-type, and finally the trees
Betula undiff. and later Pinus and Picea, as the forest reverted back towards a more natural state.

Reindeer herding can be distinguished most clearly in the coprophilous fungal spore record from a peat profile collected inside an annex to the renvall. This signal appears to weaken significantly over a short distance $(<15 \mathrm{~m})$ from the source of the activity due to the limited capacity for dispersal of these types of spores. Differences in the impact of intensive and extensive reindeer herding are most apparent in the records for coprophilous fungal spores. During intensive reindeer herding, small numbers of animals would have spent several weeks at the renvall, resulting in an increase in the abundance and community diversity of coprophilous fungal spores. This is in contrast to large herds spending up to one full day at the site during the extensive reindeer herding period, during which the input of these NPPs is relatively muted. This demonstrates that not just herd size, but the duration of reindeer presence on the site, also influences the abundance of coprophilous fungal spores recorded in the fossil record.

Acknowledgements This research was funded by the Leverhulme Trust through the Footprints on the Edge of Thule project, and was written under the auspices of the ERC-funded project Arctic Domus. Thanks are offered to Audrey Innes for laboratory assistance; Ian Foster for ${ }^{210} \mathrm{~Pb}$ dating; Gordon Cook for AMS radiocarbon analyses; and Martin Konert and the late Sjoerd Bohncke for assistance with LOI and related analyses. The comments of Tim Mighall, Jeff Blackford, Mari Kuoppamaa, two anonymous referees and the editor helped to improve the paper.

Open Access This article is distributed under the terms of the Creative Commons Attribution 4.0 International License (http://crea tivecommons.org/licenses/by/4.0/), which permits unrestricted use, distribution, and reproduction in any medium, provided you give appropriate credit to the original author(s) and the source, provide a link to the Creative Commons license, and indicate if changes were made.

\section{References}

Appleby PG, Nolan PJ, Gifford DW, Godfrey MJ, Oldfield F, Anderson NJ, Battarbee RW (1986) ${ }^{210} \mathrm{~Pb}$ dating by low background gamma counting. Hydrobiologia 143:21-27

Aronsson K- $\AA$ (1991) Forest reindeer herding AD 1-1800: an archaeological and palaeoecological study in northern Sweden. Archaeology and Environment vol 10. Department of Archaeology, University of Umeå, Umeå

Aronsson K-Å (1994) Pollen evidence of Saami settlement and reindeer herding in the boreal forest of northernmost Swedenan example of modern pollen rain studies as an aid in the interpretation of marginal human interference from fossil pollen data. Rev Palaeobot Palynol 82:37-45

Baker AG, Bhagwat SA, Willis KJ (2013) Do dung fungal spores make a good proxy for past distribution of large herbivores? Quat Sci Rev 62:21-31

Ball DF (1964) Loss-on-ignition as an estimate of organic matter and organic carbon in non-calcareous soils. J Soil Sci 15:84-92 
Beaudoin A (2003) A comparison of two methods for estimating the organic content of sediments. J Paleolimnol 29:387-390

Behre KE (1981) The interpretation of anthropogenic indicators in pollen diagrams. Pollen Spores 23:225-245

Behre KE (1988) The rôle of man in European vegetation history. In: Huntley B, Webb T III (eds) Vegetation History. Kluwer Academic Publishers, Dordrecht, pp 633-672

Bennett KD (2015) Catalogue of pollen types. http://www.chrono. qub.ac.uk/pollen/pc-intro.html

Bennett KD (2015) Psimpoll and pscomb programs for plotting and analysis. http://www.chrono.qub.ac.uk/psimpoll/psimpoll.html

Berglund B, Gaillard M-J, Björkman L, Persson T (2008) Long-term changes in floristic diversity in southern Sweden: palynological richness, vegetation dynamics and land-use. Veget Hist Archaeobot 17:573-583

Bergman I, Olofsson A, Hörnberg G, Zackrisson O, Hellberg E (2004a) Deglaciation and colonization: pioneer settlements in northern Fennoscandia. J World Prehist 18:155-177

Bergman I, Östlund L, Zackrisson O (2004b) The use of plants as regular food in ancient Subarctic economies: a case study based on Sami use of Scots pine innerbark. Arct Anthropol 41:1-13

Bergman I, Zackrisson O, Liedgren L (2013) From hunting to herding: land use, ecosystem processes, and social transformation among Sami AD 800-1500. Arct Anthropol 50:25-39

Bjørnstad G, Flagstad Ø, Hufthammer AK, Røed KH (2012) Ancient DNA reveals a major genetic change during the transition from hunting economy to reindeer husbandry in northern Scandinavia. J Archaeol Sci 39:102-108

Blaauw M (2010) Methods and code for 'classical' age-modelling of radiocarbon sequences. Quat Geochronol 5:512-518

Blaauw M, Christen JA (2011) Flexible paleoclimate age-depth models using an autoregressive gamma process. Bayesian Anal 6:457-474

Bogoras W (1924) New problems of ethnographical research in polar countries. Paper presented at the Proceedings of the 21st international congress of Americanists, Leiden

Bradshaw RHW, Zackrisson O (1990) A two thousand year history of a northern Swedish boreal forest stand. J Veg Sci 1:519-528

Caseldine C (2001) Changes in Betula in the Holocene record from Iceland-a palaeoclimatic record or evidence for early Holocene hybridisation? Rev Palaeobot Palynol 117:139-152

Chambers FM, van Geel B, van der Linden M (2011) Considerations for the preparation of peat samples for palynology, and for the counting of pollen and non-pollen palynomorphs. Mires Peat $7: 1-14$

Clark JS (1988) Particle motion and the theory of charcoal analysis: source area, transport, deposition, and sampling. Quat Res 30:67-80

Conedera M, Tinner W, Neff C, Meurer M, Dickens AF, Krebs P (2009) Reconstructing past fire regimes: methods, applications, and relevance to fire management and conservation. Quat Sci Rev 28:555-576

Cugny C, Mazier F, Galop D (2010) Modern and fossil non-pollen palynomorphs from the Basque mountains (western Pyrenees, France): the use of coprophilous fungi to reconstruct pastoral activity. Veget Hist Archaeobot 19:391-408

Davis OK (1987) Spores of the dung fungus Sporormiella: increased abundance in historic sediments and before Pleistocene megafaunal extinction. Quat Res 28:290-294

Davis MB, Deevey ES (1964) Pollen accumulation rates: estimates from late-glacial sediment of Rogers Lake. Science $145: 1,293-1,295$

Davis OK, Shafer DS (2006) Sporormiella fungal spores, a palynological means of detecting herbivore density. Palaeogeogr Palaeoclimatol Palaeoecol 237:40-50
Edwards KJ (1996) A Mesolithic of the western and northern Isles of Scotland? Evidence from pollen and charcoal. In: Pollard T, Morrison A (eds) The early prehistory of Scotland. Edinburgh University Press, Edinburgh, pp 23-38

Edwards KJ, MacDonald GM (1991) Holocene palynology: II human influence and vegetation change. Prog Phys Geogr 15:364-391

Edwards KJ, Rowntree KM (1980) Radiocarbon and palaeo-environmental evidence for changing rates of erosion at a Flandrian stage site in Scotland. In: Cullingford RA, Davidson DA, Lewin J (eds) Timescales in geomorphology. Wiley, Chichester, pp 207-223

Edwards KJ, Schofield JE, Whittington G, Melton ND (2009) Palynology 'on the edge' and the archaeological vindication of a Mesolithic presence? The case of Shetland. In: Finlay N, McCartan S, Milner N, Wickham-Jones CR (eds) From bann flakes to bushmills - papers in honour of Professor Peter Woodman. Prehistoric Society Paper 1 and Oxbow Books, Oxford, pp 113-123

Ericsson S, Östlund L, Axelsson A-L (2000) A forest of grazing and logging: deforestation and reforestation history of a boreal landscape in central Sweden. New For 19:227-240

Evans R (1996) Some impacts of overgrazing by reindeer in Finnmark, Norway. Rangifer 16:3-16

Feeser I, O'Connell M (2010) Late Holocene land-use and vegetation dynamics in an upland karst region based on pollen and coprophilous fungal spore analyses: an example from the Burren, western Ireland. Veget Hist Archaeobot 19:409-426

Feranec RS, Miller NG, Lothrop JC, Graham RW (2011) The Sporormiella proxy and end-Pleistocene megafaunal extinction: a perspective. Quat Int 245:333-338

Foster IDL, Boardman J, Keay-Bright J (2007) Sediment tracing and environmental history for two small catchments, Karoo Uplands, South Africa. Geomorphology 90:126-143

Freschet GT, Östlund L, Kichenin E, Wardle DA (2014) Aboveground and belowground legacies of native Sami land use on boreal forest in northern Sweden 100 years after abandonment. Ecology 95:963-977

Goring S, Williams JW, Blois JL et al (2012) Deposition times in the northeastern United States during the Holocene: establishing valid priors for Bayesian age models. Quat Sci Rev 48:54-60

Grimm EC (1987) CONISS: a FORTRAN 77 program for stratigraphically constrained cluster analysis by method of incremental sum of squares. Computers Geosci 13:13-35

Grimm EC (1990) TILIA and TILIA*GRAPH: PC spreadsheet and graphics software for pollen data. INQUA Working Group on Data-Handling Methods

Helskog K (1988) Helleristningene i Alta. Spor etter ritualer og dagiliv i Finnmarks forhistorie, Alta

Hicks S (1976) Pollen analysis and archaeology in Kuusamo, northeast Finland, an area of marginal human interference. Trans Inst Br Geogr 1:362-384

Hicks S (1993) Pollen evidence of localized impact on the vegetation of northernmost Finland by hunter-gatherers. Veget Hist Archaeobot 2:137-144

Hicks S, Hyvärinen H (1999) Pollen influx values measured in different sedimentary environments and their palaeoecological implications. Grana 38:228-242

Hörnberg G, Bohlin E, Hellberg E, Bergman I, Zackrisson O, Olofsson A, Wallin J-E, Påsse T (2005) Effects of Mesolithic hunter-gatherers on local vegetation in a non-uniform glacio-isostatic land uplift area, northern Sweden. Veget Hist Archaeobot 15:13-26

Ingold CT (1971) Fungal spores: their liberation and dispersal. Clarendon Press, Oxford

Jochelson W (1926) The Yukaghir and the Yukaghirized Tungus. In: Brill EJ (ed) The Jesup North Pacific Expedition, vol 9. Memoirs 
of the American Museum of Natural History, Leiden, pp 343-469

Jonsson BG, Esseen P-A (1998) Plant colonisation in small forestfloor patches: importance of plant group and disturbance traits. Ecography 21:518-526

Josefsson T, Hörnberg G, Östlund L (2009) Long-term human impact and vegetation changes in a boreal forest reserve: implications for the use of protected areas as ecological references. Ecosystems 12:1,017-1,036

Josefsson T, Gunnarson B, Liedgren L, Bergman I, Östlund L (2010) Historical human influence on forest composition and structure in boreal Fennoscandia. Can J For Res 40:872-884

Karlsson H, Hornberg G, Hannon G, Nordstrom EM (2007) Longterm vegetation changes in the northern Scandinavian forest limit: a human impact-climate synergy? Holocene 17:37-49

Kuoppamaa M, Goslar T, Hicks S (2009) Pollen accumulation rates as a tool for detecting land-use changes in a sparsely settled boreal forest. Veget Hist Archaeobot 18:205-217

Landi M, Zoccola A, Gonnelli V et al (2016) Effect of grazing on the population of Matteuccia struthiopteris at the southern limit of its distribution in Europe. Plant Species Biol 31:3-10

Lendvay B, Kalapos T (2014) Population dynamics of the climatesensitive endangered perennial Ferula sadleriana Ledeb. (Apiaceae). Plant Species Biol 29:138-151

Lindholm M, Aalto T, Grudd H, McCarroll D, Ogurtsov M, Jalkanen R (2012) Common temperature signal in four well-replicated tree growth series from northern Fennoscandia. J Quat Sci 27:828-834

Lundmark L (2007) Reindeer pastoralism in Sweden 1550-1950. Rangifer Rep 12:9-16

Mäkelä E, Hyvärinen H (1998) Holocene vegetation history at Vätsäri, inari Lapland, northeastern Finland, with special reference to Betula. Holocene 10:75-85

Manker E (1947) De Svenska fjällapparna vol 4. Handböcker om det svenska fjället. Svenska Turistföreningens Förlag, Stockholm

Mauquoy D, van Geel B, Blaauw M, van der Plicht J (2002) Evidence from northwest European bogs shows 'Little Ice Age' climatic changes driven by variations in solar activity. Holocene 12:1-6

Möller P, Östlund O, Barnekow L, Sandgren P, Palmbo F, Willerslev E (2013) Living at the margin of the retreating Fennoscandian Ice Sheet: the early Mesolithic sites at Aareavaara, northernmost Sweden. Holocene 23:104-116

Mooney SD, Tinner W (2011) The analysis of charcoal in peat and organic sediments. Mires Peat 7(9):1-18

Moore PD, Webb JA, Collinson ME (1991) Pollen analysis, 2nd edn. Blackwell, Oxford

Mossberg B, Stenberg L (2010) De nya Nordiska floran. Bonnier Fakta, Stockholm

Müller-Wille L, Heinrich D, Lehtola VP, Aikio P, Konstantinov Y, Vladimirova V (2006) Dynamics in human-reindeer relations: reflections on prehistoric, historic and contemporary practices in northernmost Europe (Ecological Studies; Reindeer Management in Northernmost Europe, vol 184). Springer, Berlin, pp $27-45$

Niklasson M, Granström A (2000) Numbers and sizes of fires: longterm spatially explicit fire history in a Swedish boreal landscape. Ecology 81:1,484-1,499

Niklasson M, Zackrisson O, Östlund L (1994) A dendroecological reconstruction of use by Saami of Scots pine (Pinus sylvestris L.) inner bark over the last 350 years at Sädvajaure, N. Sweden. Veget Hist Archaeobot 3:183-190

Östlund L (1995) Logging the virgin forest: northern Sweden in the early-nineteenth century. For Conserv Hist 39:160-171

Östlund L, Bergman I (2006) Cultural landscapes in northern forests - time, space and affiliation to the land. In: Agnoletti M (ed) The conservation of cultural landscapes. CABI Publishing, Wallingford, pp 30-41
Östlund L, Ericsson TS, Zackrisson O, Andersson R (2003) Traces of past sami forest use: an ecological study of culturally modified trees and earlier land use within a boreal forest reserve. Scand J For Res 18:78-89

Patterson WA, Edwards KJ, Maguire DJ (1987) Microscopic charcoal as a fossil indicator of fire. Quat Sci Rev 6:3-23

Raper D, Bush M (2009) A test of Sporormiella representation as a predictor of megaherbivore presence and abundance. Quat Res 71:490-496

Reimer PJ, Bard E, Bayliss A et al (2013) IntCal13 and Marine13 radiocarbon age calibration curves $0-50,000$ years cal BP. Radiocarbon 55:1,869-1,887

Ruong I (1982) Samerna i historien och nutiden. Bonnier Fakta, Stockholm

Salmonsson J (2003) Human impact on the forest line: a pollen analytical study in connection to stalo dwellings in Vindelfjällen nature reserve, northern Sweden. Sveriges Lantbruksuniversitet, Uppsala

Scott D (2001) Recovery of a dwarf birch (Betula nana) population following reduction in grazing by red deer (Cervus elaphus). Bot J Scotl 53:155-167

Seppä H, Hicks S (2006) Integration of modern and past pollen accumulation rate (PAR) records across the arctic tree-line: a method for more precise vegetation reconstructions. Quat Sci Rev 25:1,501-1,516

Seppä H, Bjune AE, Telford RJ, Birks HJB, Veski S (2009) Last ninethousand years of temperature variability in Northern Europe. Clim Past 5:523-535

Sørensen L, Mikola J, Kytöviita M-M, Olofsson J (2009) Trampling and spatial heterogeneity explain decomposer abundances in a sub-arctic grassland subjected to simulated reindeer grazing. Ecosystems 12:830-842

St. Amour NA, Hammarlund DAN, Edwards TWD, Wolfe BB (2010) New insights into Holocene atmospheric circulation dynamics in central Scandinavia inferred from oxygen-isotope records of lake-sediment cellulose. Boreas 39:770-782

Staland H, Salmonsson J, Hörnberg G (2011) A thousand years of human impact in the northern Scandinavian mountain range: long-lasting effects on forest lines and vegetation. Holocene 21:379-391

Stockmarr J (1971) Tablets with spores used in absolute pollen analysis. Pollen Spores 13:615-621

Stuiver M, Reimer PJ (1993) Extended ${ }^{14} \mathrm{C}$ data base and revised CALIB $3.0{ }^{14} \mathrm{C}$ age calibration program. Radiocarbon 35:215-230

Stuiver M, Reimer PJ, Reimer R (2005) CALIB radiocarbon calibration. http://calib.qub.ac.uk/calib/

Suominen J (1975) On the plant cover at sites of ancient Lapp winter villages, Finnish Lapland. Luonnon Tutkija 79:92-94

Suominen O, Olofsson J (2000) Impacts of semi-domesticated reindeer on structure of tundra and forest communities in Fennoscandia: a review. Ann Zool Fenn 37:233-249

Ter Braak CJF (1995) Ordination. In: Jongman RHG, Ter Braak CJF, Van Tongeren OFR (eds) Data analysis in community and landscape ecology. Cambridge University Press, Cambridge, pp 91-173

Ter Braak CJF, Smilauer P (2002) CANOCO reference manual and CanoDraw for Windows user's guide: software for canonical community ordination (version 4.5). Microcomputer Power, Ithaca

Troels-Smith J (1955) Karakterisering af løse jordater (Characterization of unconsolidated sediments). Danm Geol Unders 3:1-73

Van Dyke H (1901) Fisherman's luck and some other uncertain things. Charles Scribner's Sons, New York

Van Geel B, Buurman J, Brinkkemper O, Schelvis J, Aptroot A, van Reenen G, Hakbijl T (2003) Environmental reconstruction of a Roman Period settlement site in Uitgeest (The Netherlands), with special reference to coprophilous fungi. J Archaeol Sci 30:873-883 
Väre H, Ohtonen R, Oksanen J (1995) Effects of reindeer grazing on understorey vegetation in dry Pinus sylvestris forests. J Veg Sci 6:523-530

Vuorela I (1976) An instance of slash and burn cultivation in southern Finland investigated by pollen analysis of a mineral soil. Mem Soc Fauna Flora Fenn 52:29-46

Walker LR, Wardle DA (2014) Plant succession as an integrator of contrasting ecological time scales. Trends Ecol Evol 29:504-510

Woelders L, Bos JAA, de Kort J-W, Hoek WZ (2016) Early Holocene environmental change and the presence of Mesolithic people in the Tungelroyse Beek valley near Mildert, the Netherlands. Veget Hist Archaeobot 25:177-189

Wood JR, Wilmshurst JM (2012) Wetland soil moisture complicates the use of Sporormiella to trace past herbivore populations. J Quat Sci 27:254-259

Yafetto L, Carroll L, Cui Y et al (2008) The fastest flights in nature: high-speed spore discharge mechanisms among fungi. PLoS ONE 3:e3237 